Mustafa YENIASIR
Burak GÖKBULUT

Tülay KAYA TEKMAN****

Anahtar Kelimeler

Kıbrıs, Anadolu, Türk halk masalları, kültürel unsur, karşılaştırma, folklor

Keywords

Cyprus, Anatolia, Turkish folk tale, cultural element, comparison, folklore

**Doç. Dr., Yakın Doğu Üniversitesi,

Atatürk Ĕ̆itim Fakültesi, Türkçe

Öğretmenliği Bölümü

mustafa.yeniasir@neu.edu.tr

ORCID: 0000-0002-9196-1805

Lefkoşa/Kuzey Kıbrıs

Türk Cumhuriyeti

***Doç. Dr., Yakın Doğu Üniversitesi Atatürk Ĕ̆itim Fakültesi, Türkçe

Öğretmenliği Bölümü burak.gokbulut@neu.edu.tr ORCID: 0000-0003-3968-9207

Lefkoşa/Kuzey Kıbrıs

Türk Cumhuriyeti

****Uzm., TED Kuzey Kıbrıs Koleji tly.06@hotmail.com

ORCID: 0000-0003-0200-047X

Lefkoşa/Kuzey Kıbrıs

Türk Cumhuriyeti

Gönderim Tarihi: 19/10/2020

Kabul Tarihi: $\quad$ 08/06/2021

\section{ANADOLU VE KIBRIS TÜRK HALK MASALLARINDA YER ALAN KÜLTÜREL UNSURLAR ÜZERİNE BİR KARŞILAŞTIRMA*}

\section{A COMPARISON ON THE CULTURAL ELEMENTS OF ANATOLIAN AND TURKISH CYPRIOT FOLK TALES}

\section{$\ddot{O} z$}

Anadolu ve Kıbrıs Türk halk masalları benzer kaynaklardan beslenen; ortak içerik, yapı, şekil ve işlev özelliklerini barındıran sözlü anlatmalardır. Kıbrıs Türkleri Anadolu'dan adaya göç ederlerken geldikleri bölgelerin kültürlerini, sosyal anlayışlarını, inançlarını ve anlatmalarını da birlikte getirmişler ve zaman içinde ada kültürüyle bunları harmanlayıp gelecek nesillere aktarmışlardır. Kıbrıs Türk halkı da ada coğrafyasına bă̆hl olarak çeşitli yer isimlerini, coğrafi şekilleri, sosyal şartları da yıllar içerisinde halk masalları bünyesinde eritmiş ve Anadolu'dan farklı birçok unsuru da masalların içeriğine eklemiştir. Örneğin; Rumlarla yaşamanın getirisi olarak papaz tipi ve çeşitli Rum karakterler masallarda yer alırken Hristiyan kültürüne ait farklı unsurlar da anlatmalarda geçmektedir. Anadolu ve Kıbrıs Türk masallarında yer alan kültürel unsurlar değerlendirilirken mutfak kültürü, el sanatları, el işleri, inançlar, din, sosyal hayat, mimari, oyunlar, düğ̈̈n, çeyiz, şölen-ziyafet, masal motifleri, halk tipleri vb. göz önünde bulundurmuş ve bu kültürel unsurların masallarda nasıl yer aldığı ortaya konmuştur.

Araştırmada Anadolu ve Kıbrıs Türk halk masalları arasında benzer birçok kültürel unsur tespit edilmiştir. Çalışmada araştırma yöntemi olarak nitel araştırma uygulanmış ve verileri toplamak amacıyla doküman analizi kullanılmıştır.

\section{Abstract}

Anatolian and Turkish Cypriot folk tales are oral narratives that are fed by similar sources and contain common content, structure, form, and function features. While the Turkish Cypriots migrated from Anatolia to the island, they brought together the cultures, social insights, beliefs, and narratives of the regions they came from and blended them with the island culture and transferred them to future generations. Depending on the island geography, the Turkish Cypriot people melted various place names, geographical shapes, and social conditions within the folk tales over the years and added many different elements from Anatolia to the fairy tales. For example, the priest type and various Greek characters take part in fairy tales as well as different elements of Christian culture are mentioned in the narrations. While evaluating the cultural elements in Anatolian and Turkish Cypriot tales, culinary culture, handicrafts, crafts, beliefs, religion, social life, architecture,

* Bu çalışma 19-22 Nisan 2019 tarihleri arasında Bahçeşehir Üniversitesi Lefkoşa Kampüsünde düzenlenen "International Congress on Afro-Eurasian Research V" adlı kongrede bildiri olarak sunulmuş ancak basılmamıştır. Makale söz konusu bildirinin genişletilmiş ve yeniden düzenlenmiş şeklidir.. 


\section{5ELÇUKTÜRKIYAT}

games, weddings, dowry, feast-banquet, fairy-tale motifs, folk types etc. were taken into consideration as well as how these cultural elements take place in fairy tales. Many similar cultural elements have been identified between Anatolian and Turkish folk tales. Qualitative research was applied as a research method and document analysis was used to collect data. 


\section{Giriş}

Masallar, yapı, içerik ve işlev özellikleriyle kendine has unsurları barındıran, motiflerle tasvirleri içeren, tekerlemelerle zenginleştirilen bir türdür. İçerik özellikleri bakımından olağanüstü ve hayalî unsurlarla döşenmiş, gerçek zamanın ve mekânın belirgin olmadığı genellikle mutlu sonla biten halk masalları, birçok kültürel unsuru da içeriğinde barındırmaktadır (Gökbulut, 2010). Özellikle sosyokültürel unsurlar bakımından ait olduğu toplumun birçok özelliğini içerisinde eriten halk masalları toplumun ve kişilerin bilinçaltını örtük bir şekilde içermekte ve toplumun yapısıyla ilgili araştırmacılara önemli bilgiler sunmaktadır.

Bu bağlamda Şimşek de sözlü kaynaklardan tespit edilen masalların sadece edebî açıdan değil antropolojik, sosyolojik, psikolojik açılardan da incelenmesi gerektiğini belirtmiştir (Şimşek, 2001, s. 200).

Halk masallarının kültürü barındırma ve aktarma rolü bir toplum için oldukça önemlidir. Çünkü çocukların sosyal, bilişsel ve ahlaki yönlerden eğitilmesini ve gelişmesini (Kantarcıoğlu, 1991, s. 26-28, 30-34) sağlayan masalların bu işlevi yeni neslin kültürlenmesini sağlamaktadır. Çocuklar bir masalı dinlerken veya okurken kendi kültürüyle ilgili birçok unsuru da öğrenmekte ve benimsemektedir (Sakaoğlu, 2002, s. 12). Söz gelimi, çocuk masalda duyduğu bir inanışı, geleneksel bir yemeği, içeceği, kaybolmaya yüz tutmuş eski bir mesleği, el sanatını vs. masaldan öğrenir. Bu anlamda masallar zengin kültür içeriğiyle incelenmeye değer türlerden biridir. Bu bağlamda çalışmada masallar mekânlar, ev eşyaları, ekonomi türleri, meslek, beslenme-mutfak ve kiler, ölçme-tartma-hesaplama birimleri, giyim-kuşam ve süs, halk hekimliği, halk inançları; töreler, âdetler, gelenekler-görenekler, geçiş dönemleri, misafirperverlik, dinsel-büyüsel inançlar, halk edebiyatı, halk sporları, yetişkin ve çocuk oyunları, taşıtlar- taşıma teknikleri, halk sanatları ve zanaatları yönlerinden incelenmiş ve tespit edilen unsurlar Anadolu ve Kıbrıs Türk kültürüyle ilişkilendirilerek incelenmiştir.

\section{ARAŞTIRMANIN METODOLOJISİ}

\subsection{Araştırma Modeli}

Çalışmada nitel araştırma yöntemi uygulanmış ve verileri toplamak amacıyla doküman analizi tekniğinden faydalanılmıştır.

\section{2. Çalışmanın Örneklemi}

Çalışmanın örneklemini Türkiye ve Kıbrıs sahası Türk halk masallarından seçilen toplamda 40 masal (20 Anadolu -20 Kıbrıs) oluşturmaktadır.

Anadolu Türk halk masalları Ali Berat Alptekin (2002)'in Taşeli Masalları, Saim Sakaoğlu'nun (2002) Gümüşhane ve Bayburt Masalları ve Naki Tezel'in (1992) Türk Masalları II adlı kitaplarından seçilirken Kıbrıs Türk halk masalları Oğuz Yorgancıoğlu'nun Kıbrıs Türk Folklorundan Derlemeler-Masallar II (2006) adlı kitabından alınmıştır. 
Çalışmada incelenen Kıbrıs Türk Halk masalları (20 masal) şunlardır: Akıldane (1012), Tembel Cingöz (13-15), Sağır İlan Meseli (15-17), Beddualı Çocuk (23-25), Deli Behlül'ün Aglı (27-30), Gecegezen (30-31), Hakyemek Gardaşlar (32-34), Dinsizin Hakkından İmansız Gelir (35-37), Yemeyenin Yeyicisi Var (37-39), Yazılan Bozulmaz (39-42), Bir Çocuum Olsun Da İsdersa İlan olsun (42-47), Dilsiz Şahit (47-55), İlahim Damın Agsın Da Gazanın Altına Saklanasın (56-57), Senin Kismetin Budur (68-71), Padişahısan Her Şeyi Bilemen Ya! (71-74), Uyuyan Güzel (75-78), Padişahınan Gızları (87-89), Sihirli Tencere (113-115), Hamarat Gadın ve Naletli Köprü (149-151), Güvercin Şehzade (152-153).

Anadolu halk masalları (20 masal) ise şunlardır: Kırk Oğlan (1-8), Güneş Kızı (929), Altın Araba (30-36), Rüzgaroğlu (37-48), Sihirli Tavşan (49-69), Limon Kız (70-77), Tuz (78-93), Kırk Haramiler (94-101), Doğruluk (102-122), Keloğlan'ın Köse'ye Masalı (150-153), Hamamcı ile Keloğlan (154-162), Avcı Ahmet (224-229), Havva Hanım (230232), Aslan Mehmet (233-237), Hanımından Korkan Osman Ağa (238-240), Padişahın Üç Kızı (241-247), Küllü Fatma (248-250), Yemen Padişahının Oğlu (479-481), Üç Dokumacı Kardeş (347-350), Padişahlar Padişahı (351-355) (Alptekin, 2002; Sakaoğlu, 2002; Tezel, 1992).

\subsection{Veri Toplama ve Analiz Yöntemi}

Çalışmada masallar betimsel analiz yoluyla çözümlenmiş ve masalların kültürel özellikleri tespit edilerek karşılaştırılmış ve yorumlanmıştır. Bu çalışmada verileri toplamak amacıyla doküman analizi kullanılmıştır: "Doküman incelemesi, araştırılması hedeflenen olgu veya olgular hakkında bilgi içeren yazll materyallerin analizini kapsar" (Şimşek ve Yıldırım, 2013, s. 218).

\section{4. Çalışmanın Amacı}

Çalışmanın amacı Türkiye ve Kuzey Kıbrıs sahası Türk halk masallarını kültürel bağlamda karşılaştırarak, benzerlikleri ortaya koymak ve buradan hareketle tespit edilen unsurların yorumunu yapmaktır.

\section{BULGULAR VE YORUMLAR}

Çalışmanın bulgular ve yorumlar kısmında Anadolu ve Kıbrıs Türk halk masallarında tespit edilen kültürel unsurlar verilmiş ve bunlar üzerine yorumlar yapılmıştır. Böylece her iki ülkenin masallarında yer alan kültürel unsurların benzer yönleri ortaya konmuştur.

\subsection{Mekânlar-Yerleşim Türleri}

\subsubsection{Konak}

Konaklar özellikle 19. yüzyılın son çeyreğine kadar Türk kültüründe önemli bir yere sahiptir. Çünkü konaklar sadece yaşanılan yer değil aynı zamanda devlet işlerinin yürütüldüğü, toplantıların gerçekleştirildiği, seyyah ve alimlerin misafir olarak ağırlandığı geleneksel bir mekân olarak bilinmektedir.

Anadolu Türk halk masallarından "Güneş Kızı" masalında konak "Günlerce yol aldıktan sonra dağ başında bir konağa misafir olmuş. Meğer orası dev konağı imiş. Devin kızı insanoğlu sen buraya nereden geldin bu konă̆ın bir dev konă̆ı olduğunu sana söylemediler mi 
demiş" (Tezel, 1992, s. 9-29) şeklinde, "Doğruluk" adlı masalda "Buranın bir dev konağ 1 olduğunu anlayan oğlan, fena halde korkmuş" (Tezel, 1992, s. 123-139) şeklinde, "Üç Dokumacı Kardeş" masalında ise "Ahmet şehirde bir yapı alır. Ertesi gün gidip kızları getirir. Onları konakta bıraktıktan sonra padişaha gider" şeklinde geçmektedir (Sakaoğlu, 2002, s. 347-350).

Kıbrıs Türk halk masallarından "Güvercin Şehzade" masalında konak "Gız bırakmış işini gücünü, düşmüş güvercinin peşine. Ipliği takip ede ede gitmiş bir gonă̆a" (Yorgancioğlu, 2006, s. 152-153) şeklinde geçmektedir. "Hakyemez Gardaşlar" masalında ise konak "Illahim Tangrım da bu davarılan bu gonak hem içindekiler geldikleri gibin gitsinner demiş. Ne davar ne gonag galmamış" şeklinde ifade edilmiştir (Yorgancioğlu, 2006, s. 32-34).

Konak hem masalların oluştuğu eski Osmanlı hem de Kıbrıs coğrafyasında önemli halk mimarisi yapılarından biridir. Türk halk mimarisinde önemli bir karakteristik yapı arz eden ve şehirlerin kültürel kimliğini şekillendiren konaklar Türklerin sosyal yaşamında da etkilidir. Bu nedenle Anadolu ve Kıbrıs Türk halk masallarında konak mimari bir yapı olarak karşımıza çıkmaktadır.

\subsubsection{Aşevi}

Aşevi Türk mutfak kültürünün önemli bir parçasıdır. İhtiyaçlı insanlara yemek dağıtılan bir yer olan aşevi Anadolu ve Kıbrıs halk ağılarında evlerdeki mutfağın da diğer adıdır. Aşevleri Türk yardımseverliğinin ve tarihten gelen birlik olma ve yardımlaşma kültürünün de bir göstergesidir. Sadece İslamiyet sonrasında değil öncesinde de Türklerde halka yardım ve ziyafet verme mevcuttur.

İncelenen masallar göz önünde bulundurulduğunda Anadolu halk masallarında aşevine rastlanmazken Kıbrıs Türk halk masallarında bunun 6 masalda geçtiği görülmektedir. Bu masallar; "Hakyemez Gardaşlar", "Yemeyenin Yeyicisi Var", "Yazılan Bozulmaz", "Dilsiz Şahit", "Padişahısan Herşeyi Bilemen Ya" ve "Güvercin Şehzade" masallarıdır. Örneğin; "Yemeyenin Yeyicisi Var" masalında "Adam almış aşevinden bir kepce hem bir şişe da garayağ(zeytinyağı) doldurmuş. Götürmüş evine" (Yorgancıoğlu, 2006, s. 37-39) şeklinde, "Yazılan Bozulmaz" masalında da "Adam gene gaçar gibi yapmış da saglanmış. Garı aşevine girinca adam cebindeki biççă̆̆ gızzın gasıklarına saplamış" (Yorgancıoğlu, 2006, s. 39-43) şeklinde görülür.

\subsubsection{Han}

Hanlar Türklerin eski dönemlerde hayvanlarla yolculuk ve ticari taşımacılık yaptığı zamanlarda kullandıkları konaklama yerleridir. $\mathrm{Bu}$ mekânlar Türk misafirperverliğinin bir göstergesidir. Ayrıca Türklerdeki güçlü devlet geleneğinin de önemli bir unsurudur. Türk sosyal yaşamın önemli bir unsuru olan hanlar masallarda da geçmektedir.

Anadolu masallarından "Sihirli Tavşan", "Kırk Haramiler" ve "Doğruluk" masallarında han ve hancıya yer verilmiştir. Örneğin; "Doğruluk" adlı masalda han "Oğlan sabaha karşı bir kasabaya varmış. Gidip bir hana yerleşerek karnını doyurduktan sonra, uykuya yatmış. Akşama yakın uyanmış. Hemen dışarı çıkarak güzel bir at satın almış. Heybelerine yiyecek doldurarak Hindistan'ın yolunu tutmuş. Hindistan'a ulaşmış. Hint 
padişahının oturduğu şehri öğrendikten sonra, oraya gidip bir hana yerleşmiş." (Tezel, 1992, s. 123-139) şeklinde geçerken, "Kırk Haramiler" masalında ise "Sultan ve kervan başı gitmişler, gitmişler, günlerce, haftalarca yol aldıktan sonra nihayet Mısır'a ulaşmışlar. Kervan başı nereye giderse o da arkasından gidiyormuş. Kervan bir hana yerleşmiş" şeklinde geçmektedir (Tezel, 1992, s. 102-122).

Kıbrıs Türk masallarından "Padişahısan Her Şeyi Bilemen Ya" adlı masalda "Adam almış garıları düşmüş yola. Önce varmış hana. Demiş hancıya" cümlesinde han ve hancıya yer verildiği görülmektedir (Yorgancıŏlu, 2006, s. 71-74).

Görüldügü üzere han Anadolu ve Kıbrıs Türk halk masallarında sıkça geçmekte ve metinlerde Türk sosyal yaşamındaki hanlarla benzer işlevde yer aldığı görülmektedir.

\subsubsection{Hamam}

Türk kültüründe hamamlar sosyal yaşantının ve halk mimarisinin önemli bir parçası olmuştur. Sadece yıkanma ve temizlenme amaçlı değil aynı zamanda suyun şifa vermesi, kutsal sayılması yönünden de önemli bir yere sahiptir.

Hamam, Anadolu Türk halk masallarından "Hamamcı ile Keloğlan", "Kırk Haramiler", "Doğruluk" ve "Küllü Fatma" masallarında geçmektedir. Örneğin; "Hamamcı ile Keloğlan" masalında şu şekilde geçmektedir. "Keloğlan, hamamcıya hiç tavrın bozmadan: -Yüksek bir yerden düşmüşsün, demiş, ben seni iyi ederim. Yalnız seni hamama götüreceğim. Fakat, yanımızda kimse olmayacak! Beraber hamama gitmişler. Keloğlan hamamın kapısını kapamış, adamı güzelce soyarak başını sabunlamış ve kurnada hiç su bırakmamış. Eline geçirdiği bir kırbaçla hamamcıyı evire çevire dövmüş. Bir de bakmışlar ki, adamcă̆ız daha perişan bir halde taşların ortasında yatıyor" (Tezel, 1992, s. 154-162).

İncelenen masallarda Kıbrıs Türk masallarında hamama yer verilmemiştir.

\subsubsection{Mağara}

Türk mitolojik ve Şamanistik inanışlarında mağara kötü ruhların yaşadığı yer altı dünyasıyla bağlantı kuran bir mekân olarak tasavvur edilmiştir. "Eski Türk inançlarında mağaralar yer altı dünyalarına açılan kapılar olarak düşünülmüştür" (Bars, 2017, s. 79). Türklerin üç katmanlı evren tasarımında yer altı kötü ruhların da dünyasıdır. "Mağara hem gerçek manada hem de sembolik manada bir geçiş mekânı olarak düşünülebilir. Birey hem boyut değiştirir hem de bulunduğu mekândan başka bir mekâna geçerken mağara, ara bir mekân olarak kabul edilebilir. Şamanizm inancına göre yer altı kutsal bir mekândır. Ancak bu mekâna kötü ruhlar gitmektedir. Sadece arınmış, temiz ruhlar oradan çıkmaktadır. Mağaranın halk anlatılarında ve modern anlatılarda da kullanılma sebebinin kaynağı Şamanizm inancına dayandırılabilir" (Çetindağ, 2007, s. 451).

İncelenen Anadolu Türk halk masallarından "Sihirli Tavşan" masalında mağara "Bir mağaraya girdi tauşan ben de arkasından girdim. Bir toprak tası işaret etti içindekinden içmemi istedi ben de içtim. İçer içmez sihirli bir tavşan oldum." (Tezel, 1992, s. 49-69) şeklinde geçmektedir. Ayrıca Türk halk masallarından "Avcı Ahmet" ve "Aslan Mehmet" adlı masallarda da mağara geçmektedir (Alptekin, 2002, s. 224-233). Örneğin Aslan Mehmet masalında çocuk dağ başında büyük bir mağaraya yerleşir ve orada yaşar (Alptekin, 2002, s. 234). 
Kıbrıs Türk halk masallarından "Sağır İlan Meseli" adlı masalda ise mağara "Kıral oğlanın elini ayağını kestirip onu bir mağaraya attırmış... Bütün yılanlar toplanıp öldürülmeğe başlanmış. Kaçıp kurtulabilen tek yılan da oğlanın atıldı̆̆ı mă̆araya sığınmış. Bakmış ki her tarafı kesilmiş yaralı bir insan... Acımış bu insana ona yardım etmeğe ve onu kurtarmağa karar vermiş. Zehrini ilaç yapmış. Bütün yaralarına sürmüş bu insanın, azar azar iyileştirmiş." (Yorgancioğlu, 2006, s. 15-17) şeklinde geçmiştir.

Her iki ülkenin masallarında mağara koruyucu bir ortam olarak karşımıza çıkmaktadır. Şamanizm'deki yer altının kutsallığı olgusu bu masallara da yansımıştır.

\subsubsection{Kuyu}

Türk kültüründe ve eski inanışlarında kuyu yer altına inerek başka bir aleme, kötü ruhların dünyasına geçişi nitelemektedir. Genellikle kişiler kuyuya kendisine kötülük yapmak isteyen biri tarafından düşürülmektedir. Çoğunlukla kişi kuyudan çıktığında bir olgunluğa erişmektedir. Bunun yanında kuyu kötülük amaçlı da anlatılarda geçmektedir. "Kuyunun hürriyetlerden mahrum etme mekânı olarak anlatılarda yer alması genellikle Tevrat'ta ve Kur'an'da yer alan 'Yusuf' kıssası ve Firdevsî'nin Şehnamesi ile ilgili olabilir. Bununla birlikte Türklerin göçebe hayat karakterine de uygun olduğunu söyleyebiliriz. Çünkü göçebe bir yaşantıda, suçluyu, çadırda veya bir bina inşa ederek hapsetmek mümkün değildir. En uygun mekân kuyu olsa gerektir. Nitekim bir hapis mekânı olarak 'kuyu' destanlarda sıkça karşımıza çıkar" (Köktürk, 2006, s. 391).

Anadolu halk masallarından "Küllü Fatma", "Aslan Mehmet", "Kırk Oğlan" masallarında, Kıbrıs Türk halk masallarından "Dinsizin Hakkından İmansız Gelir", "Uyuyan Güzel", "Hamarat Gadın ve Naletli Köprü" adlı masallarında kuyu geçmektedir.

Anadolu halk masalında "Kırk Oğlan" adlı masalda kuyu "oğlan devleri önceden hazırladığı kapalı kuyu tuză̆ının üzerine getirmiş. Devlerin hepsi de kırk kulaç derinliğindeki koca kuyuya düşmüşler." (Tezel, 1992, s. 1-8) şeklinde, "Aslan Mehmet" adlı masalda ise "anası oğlunu yedi yolun gavuşduğu yerde bir guyu varmış o guyunun içine dostuyla atıyorlar. Aslanlar gider gelir guyunun içine azıklarını atarlarmış, oğlanı beslerler. Bir adam kendir getirmiş ipi sarkıtıp çekmişler, guyudan kurtarmışlar" (Alptekin, 2002, s. 233-237) şeklinde geçmektedir.

Kıbrıs Türk halk masallarında ise "Uyuyan Güzel" masalında kuyu "Allah'ım der, bu teyzemin elinden gurtar beni. Teyze alır gardaşı gızzını da götürür bir esgi guyunun içine. Aşă̆ıda da ejderha gibin ilannar var. Gız başlar ağlamaya. Bu kısganç teyze gızzı iter düşürür guyunun içine. Kız ihtiyar bir oduncunun yardımıyla kuyudan çıkarılır" (Yorgancioğlu, 2006, s. 75-78) şeklindeki cümlelerde kuyunun olumsuz bir durumu çağriştırdığı görülür.

Görüldügü gibi kuyu genellikle masal karakterlerinin cezalandırılması veya onlara kötülük yapılması amaçlı masallarda yer almaktadır. Bu da Türk mitolojisinde kuyunun kötü ruhların bulunduğu yer altı dünyasıyla alakalı olduğunun göstergesidir. 


\subsection{Ev Eşyaları}

Halk masallarında ev içi ve dışında kullanılan eşyalarla ilgili de birçok unsur bulunmakta ve bunlar Anadolu ve Kıbrıs Türk halk masallarında da yerini bulmaktadır. Masallarda geçen eşyalar kullanım yerlerine göre sınıflandırılarak aşağıda verilmiştir.

\subsubsection{Yatak Odas1}

Anadolu Türk halk masallarında yatak odasıyla ilgili peşkir, garyola (karyola) gibi eşyalar bulunmaktadır. Peşkir kelimesi masalda "Kadın pazara gitmiş. Birkaç arşın bez alıp gelmiş, kızına vermiş. Kız bu bezden güzel peşkirler yapmış, üzerlerine iş işlemiş. Babaları da kızın yaptığı bu güzel peşkirleri pazara götürmüş." (Tezel, 1992, s. 14) şeklinde geçmekte ve üzerine işleme yapıldığı belirtilmektedir.

Kıbrıs Türk halk masallarında yatak odasıyla ilgili yatak namsiyesi (cibinlik), beşik, minder, bohça, sandık gibi eşyalar bulunmaktadır. "Bir Çocuğum Olsun da İsterse Yılan Olsun" masalında "Bebeği anasının gucağına verme. Bir ayrı beşigde dut." cümlesinde beşik geçmektedir. Yine masalın devamında ise "yatağın namsiyesini galdırı kapaklı lengeri almış" (Yorgancıoğlu, 2006, s. 42-47) şeklinde bazı eşyaların kullanıldığı görülmektedir.

\subsubsection{Mutfak}

Anadolu Türk halk masallarında mutfakla ilgili kaşık, tas, küp, sepet, kazan, kepçe, tuluk (tulum) gibi eşyalar geçmektedir. Anadolu Türk halk masallarından "Güneş Kızı" adlı masalda sandık, sepet, altın ibrik, gümüş tas unsurları yer almaktadır. Örneğin, "Ebe çocukları yanından almış, bir sandiğa koyarak dereye atmışlar." cümlesinde sandık, "bir sepetin içinde köpek yavrularını önüne getirmişler" cümlesinde sepet "Güneş kızı, o zaman: -Şu su dolu altın ibriği al, demiş. Şu gümüş tası da heybene koy" cümlesinde ise gümüş tas ve heybe geçmektedir (Tezel, 1992, s. 9-29). Masallarda geçen bu eşyalar folklorik açıdan eski Türk sosyal yaşamında kullanılan eşyaları göstermesi bakımından önemlidir.

Anadolu Türk halk masallarında sıkça geçen ocak, kutsal bir mekânı temsil etmekte ayrı bir önem arz etmektedir. Türk mitolojisinde ayrıca bir ocak kültü bulunmaktadır, Ocak otağın (yurt) ortasında bulunmasından dolayı evi temsil etmekte ve kültürümüzde önemli bir yer edinmektedir. Anadolu Türk halk masallarına bakıldığında "Doğruluk" adlı masalda ocak, "Delikanlı kocaman kocaman pencereli büyük bir binayla karşılaşmış. Açık duran kapısından içeri girince, şaşırmış. Bina bir tek büyük odadan ibaretmiş. Tavanı minare gibi yüksek olan bu odada kocaman bir ocak varmış. Ocak alev alev yanıyor, üzerindeki kazanlar fikır fikır kaynıyormuş" şeklinde karşımıza çıkmaktadır (Tezel, 1992, s. 123-139). “Ocak sistemi, ateş ve atalar kültü ile bağlantılıdır. Şamanların ayinleri ateşsiz yapmamaları, ateş ruhuna hitaben okudukları ilahilerden anlaşıldığına göre aile ocağı kültü ile ateş kültü birbirinden ayırt edilemez" (İçli, 2013, s. 97).

Kıbrıs Türk halk masallarında mutfakla ilgili drabez (masa), hasır, küp, isgemle, gazzan, kepçe, seped, taş fırın, bohça, çanak, piron (çatal) gibi eşyalar geçmektedir. "Yemeyenin Yeyicisi Var" masalında "yemeg da galmış drabezin üsdünde bitirilmemiş" (Yorgancioğlu, 2006, s. 37-39) cümlesinde drabez geçmektedir. "Bir Çocuum Olsun da İstersa İlan Olsun" masalında ise "Bir isgemle aldı, kapunun dışına oturdu." cümlesinde 
isgemle geçmektedir. Anadolu Türk halk masallarında geçen ocaklık Kıbrıs Türk halk masallarında da bulunmaktadır: Örneğin, "Tembel Cingöz" masalında "Gadın madem öyle ocaklı̆̆ın yaninda sana bir çul serecem dedi" (Yorgancioğlu, 2006, s. 13-15) cümlesinde ocak kelimesi geçmektedir. "Uyuyan Güzel" masalında da "Gadın ağrıları geçinca bagmış ocaklı̆̆ı yanında gaynanmııs süd" (Yorgancıoğlu, 2006, s. 75-78) diye geçmektedir. "Sihirli Tencere" masalında ise "Bir gocamaninan bir gocagarn da köyün bir kenarında bir gulübede yaşar. Bir göz evceğizleri var. Evin bir köşesinde da ocaklk" (Yorgancıŏlu, 2006, s. 113-115) şeklindedir.

\subsubsection{Salon/Oturma odasi}

Anadolu Türk halk masallarında sandık, tüfek, kama, inne (iğne), çıkrı gibi eşyalar bulunmaktadır. Örneğin sandık ile ilgili "Padiş̧ah yerde duran uzun sandığı göstererek: Bu sandıkta benim değerli eşyam var, demiş." (Tezel, 1992, s. 46) şeklinde bir cümle geçmektedir. Diğer bir eşya olan ayna ise şöyle geçmektedir: "Anamdan bir ayna galdl, babamdan bir hana galdr, hek edesin Havva Hanım" (Alptekin, 2002, s. 230).

Kıbrıs Türk halk masallarında bendo (beşibirlik altın), minder, bohça, sandık, kasnak, yumak, çıkın, iğne gibi eşyalar bulunmaktadır. "Yemeyenin Yeyicisi Var" masalında "Glz ölmeden demiş bu adama al bu bendoyu da garmna dakasın" cümlesinde bendo geçmektedir (Yorgancıoğlu, 2006, s. 37-39). Sandıkla ilgili olarak "Yalınız, güzel bir sandık, bir alacal entari, bir da külah isterim demiş oğlan" (Yorgancioğlu, 2006, s. 6) şeklinde bir cümle geçmektedir.

\subsubsection{Bahçe}

Anadolu Türk halk masallarında bahçeyle alakalı olarak bakraç (küçük bakır kova), ibrik, testi, muşamba gibi eşyalar görülmektedir. Örneğin "Güneş Kızı" masalında "Bir gün su bakraçlarıyla çeşmeden su alıyorlarmış" cümlesinde bakraç ve çeşme (Tezel, 1992, s. 9-29) geçerken "Güneş kızı, o zaman: -Şu su dolu altın ibriği al, demiş." cümlesinde ise ibrik geçmektedir (Tezel, 1992, s. 9-29).

Kıbrıs Türk halk masallarında bahçeyle alakalı olarak lenger (kova), desti gibi eşyalar görülmektedir. "Bir Çocuğum Olsun da İsterse Yılan Olsun" masalında "yatağın namsiyesini galdırıp kapakl lengeri almış" (Yorgancioğlu, 2006, s. 42-47) şeklindeki cümlede lengerin geçtiği görülmektedir.

Her iki ülkenin masallarında geçen eşyalara bakıldığında ev ve bahçede kullanılan geleneksel eşyalara ve eskiden günlük kullanımda olan eşyalara yer verildiği görülmektedir. $\mathrm{Bu}$ eşyalardan bazıları bugün her iki bölgede de pek fazla kullanılmayan eşyalardır.

\subsection{Ekonomi Türleri (Geçim Kaynakları)}

\subsection{Hayvancilık}

Türkler tarih boyunca konar-göçer bir yaşam şekline sahipti. Buna bağlı olarak Türklerin en önemli geçim kaynaklarından biri de hayvancllıtı. Türk kültüründe at, koyun, sığır, öküz gibi hayvanlar ve bunlara ait eşyalar önemli bir yer edinmektedir. Türkler kültür tarihi sürecinde hayvancllıta önemli gelişmeler kaydetmiş yoğurt, kımız, deri, halı, keçe vb. ürünlerle beslenme, barınma ve giyim-kuşamda hayvancilık ve buna bağlı üretimde önemli gelişmeler kaydetmiştir. Hayvancılıkla ilgili bazı unsurlar masallarda da bulunmaktadır. 
Anadolu masallarında "Avcı Ahmet" masalında Avcı Ahmet çobana misafir olur ikisi de yatar bir kalkarlar ki çoban sürüsü yok, koyunlar yayılmış, yatmış şeklinde bir anlatım bulunmaktadır (Alptekin, 2002, s. 224-229). "Konuşan Kaval" masalında da çoban korulukta koyunları otlatmaktadır (Tezel, 1992, s. 70). Yine "Altın Araba" masalında yünü kırpılmamış koç, kısrak, öküz, "Avcı Ahmet”" masalında koyun, koç, kurt gibi hayvan adları geçmektedir. Bunun yanında "Doğruluk" (Tezel, 1992, s. 123), "Konuşan Kaval" (Tezel, 1992, s. 70) masallarında at geçmektedir.

Kıbrıs Türk masalı olan "İlahim Damın Agsın da Gazanın Altına Saklanasın" masalında "Çoban olan yaşlı gadının bin baş davarı varmış. Keçi goyun garışık. Hellim ve nor yapar südlerden satarmış. Süd sayıp, damızlamayı bırakmış" cümlesinde hayvancılıktan bahsedilmektedir (Yorgancıoğlu, 2006, s. 56-57). "Senin Kısmetin Budur" masalında yine benzer şekilde hayvancılığa değinilmektedir. Örneğin, "bir çuban varımış. Yüz baş davarı varımış. Yani geçimi südden, katıgdan, yüngden, guzudan derkana epeyi gazanırmış" (Yorgancıoğlu, 2006, s. 68-71). Bunların yanı sıra mandıra, çobanlık, ahır, mera vb. unsurlar da masallarda yer almaktadir.

Anadolu ve Kıbrıs halk masallarında geçen hayvancılıkla ilgili unsurlara bakıldığında her iki toplumun da hayvancılıkla uğraşan ve bu konuda bilgisi olan toplumlar olduğu rahatlıkla söylenebilir.

\subsection{2. Çiftçilik ve tarım}

Türkler hayvancılıkla birlikte tarımsal alanda da gelişme göstermiş ve yerleşik hayata geçtikçe bu gelişmesini ilerleterek sosyal yaşamının bir parçası haline getirmiştir. Türklerde tarım, halk ekonomisinin önemli unsurlarından birini oluşturmaktadır. Yetiştirilen ürünler arasında genellikle buğday, arpa ve kendir bulunmaktadır. Çiftçilikle ile ilgili kullanılan araç-gereçler de önemli bir kültürel unsur olarak karşımıza çıkmaktadır.

Anadolu Türk halk masallarından "Rüzgaroğlu" adlı masalda ise "bir çiftçinin yanına girerek tarlada iş görmeye başlamışlar. Akşama kadar tarlada tırpan sallayıp, harmanda düven sürerek karınlarını doyurabiliyorlarmış" cümlesinde çiftçi, tarla, tırpan, harman, düven sürmek gibi geleneksel tarımla da ilgili unsurlar geçmektedir (Tezel, 1992, s. 3748). Bunun yanı sıra incelenen masallarda harmanı çekmek, orak, saban, tırpan, buğday ögütmek, değirmen gibi ifadelere de sıkça yer verilmiştir. Bu da Türklerin tarım kültürünün masallara büyük ölçülerde yansıdığını göstermektedir.

Kıbrıs Türk halk masallarından olan "Tembel Cingöz" masalında tarım ile ilgili "gider bir harmana. Harmanda bir yanda savrulmuş buğday, bir yanda övüdülen yığın, bir yanda da demetler var. Cingöz eşeği buğday demetlerinin öngüne bırağır." cümleleri geçmektedir (Yorgancioğlu, 2006, s. 14-15). Bunun yanı sıra incelenen masallarda çift sürmek, harmanda buğday, zerzevat yetiştirmek vb. ifadeler de geçmektedir.

Masallarda tarımla ilgili geçen ifadelerden yola çıkarak her iki bölgenin sosyal yaşamında tarımın önemli bir yer tuttuğu ve hayvancılıkla birlikte tarımın tarih boyunca toplumun ana geçim kaynağı olduğu söylenebilir. 


\subsubsection{Avc1l1k}

Avcılık da Türk halk ekonomisinde iki biçimde görülmektedir. Bunlar; orman (kara) ve nehir-deniz avcılığı (balıkçılık) şeklindedir. Türk tarihinin başlangıcından bugüne avcılık ve atıcılık oldukça önemli bir yer tutmuş, kültürel yaşamın bir parçası olmuştur. Oğuz Kağan destanından Dede Korkut Hikâyelerine birçok eserimizde ava çıkma önemli bir unsur olmuş, ava özel bir önem verilmiş ve geleneksel avcılığ oldukça ileriye taşımıştır. Av etinin saklanmasına, pişirilmesine, avcılıkta gerekli olan araç-gereçlere incelenen masallarda da değinilmiştir.

Anadolu masallarından "Güneş Kızı" adlı masalda orman avcılığından şöyle bahsedilmektedir: "Oğlan ava çıkmış ve çok geçmeden okla vurduğu koca bir geyiği sırtlanarak kulübeye dönmüş. Ertesi gün tekrar ava çıkmış. Ormanda dolaşırken uzaklarda birçok avcının geyiği avlamaya çalıştıklarımı, fakat onu ellerinden kaçırdıklarını görmüş. Heman bir ă̆acı siper alarak okunu atmış, geyiği yere sermiş". Yine aynı masalda ok atmayla ilgili şu ifadelere yer verilmiştir: "Meydandaki birkaç kişi ellerindeki okları atarak karşıdaki kavak ă̆acının tepesinden aşırmaya çalışıyorlar. Fakat hiçbiri de okunu aşıramıyormuş. Oku vermişler. Oğlan ilk atışta oku kavaktan aşırmış" (Tezel, 1992, s. 9-29). "Rüzgaroğlu" masalında, orman avcılığı, "Rüzgaroğlu ava meraklı olduğundan hemen bütün günlerini ormanda av peşinde geçermiş. Ceylan gibi güzel atına biner, yay gibi hızlı giden iki köpeğini yanına alır, her attığın vuran tüfeğini de omzuna asarak sabahları ava çıkarmış. O gün Rüzgaroğlunun gözüne bir geyik görünmüş. Geyiğin derisi güneş altında pırıl pırıl yanıyormuş." (Tezel, 1992, s. 37-48) şeklinde ifade edilmiştir. İncelenen Anadolu Türk halk masallarında nehir avcılığına rastlanmaz.

Kıbrıs Türk halk masallarından "Bir Çocuğum Olsun da İstersa İlan Olsun" masalında balıkçılık "Adamın bir tek balıg gamuşu varmış. Sabah gakar, bir eline sebedini alır, gamuşunu oтuzuna atar, denizin yolunu dutarmış. Öğlene gadar ne dutmuşsa, furma dalından asgı yapar, duttuğu balıkları üsdüne dizer, evine dönermiş." şeklinde geçmektedir. Orman avcılığı ise "Sağır İlan Meseli" ve "Uyuyan Güzel” masallarında geçmektedir. Örneğin; "Uyuyan Güzel” adlı masalda bu "padişahın oğlu ava meraghımış. Bir gün yolu meraya düşmüş" şeklinde geçmektedir.

Anadolu ve Kıbrıs Türk halk masallarında benzer şekilde padişah ve oğullarının ava çıktığı görülmektedir. Türk kültüründe ve destanlarında da avcılık önemli bir gelenektir ve ava çıkma belirli kurallara bağlıdır. Anadolu ve Kıbrıs Türk halk masallarının av konusunda önemli farklarından biri ise Kıbrıs masallarında görülen balıkçılığın incelenen Anadolu masallarında görülmemesidir.

\subsubsection{Halk ekonomisi}

Bilindiği gibi halk ekonomisi toplumun geçinebilmek için sürdürdüğü daha çok geleneksel faaliyetlerin tümüne denir. Halk ekonomisi hayvancılık, toplayıcılık, avcılık, balıkçılık, arıcılık, yaylacılık, bağcılık, bahçıvanlık, meyvecilik, çiftçilik, esnaflık, işçilik ve benzeri temel üretim ve tüketim tarzlarını ele almaktadır (Özarslan, 2005, s. 54).

Anadolu Türk halk masallarından "Güneş Kız" masalında ailenin "Anacığım, bari pazardan bez alsan da ben peşkir yapıp üzerine iş işlesem babam da satsa" cümlesinde peşkir yapıp sattığ1 (Tezel, 1992, s. 9-29), "Hamamcı ile Keloğlan" masalında ise "Ana oğul çok fakirimişler. Yalnız birçok tavukları olduğundan bunların yumurtasımı satarak geçinip 
giderlermiş" (Tezel, 1992, s. 9-29) cümlesinde kadının gelir amaçlı yumurta sattı̆̆1 görülmektedir. "Üç Dokumacı Kardeş" masalında ise "Halı, kilim dokur, satıp idare ederlermiş" (Sakaoğlu, 2002, s. 347-350) şeklindeki ifadeden halı ve kilim dokuyarak ekonomik kazanç elde edildiği görülmektedir.

Kıbrıs Türk halk masallarından olan "Güvercin Şehzade" masalında "Anası çamaşıra gider beş on guruş gazansın da geçinsinner. Gadın gızına da öğredmiş gergef işlemeyi, gizzına demiş hem gendi çehizini işleyesin hem da beşon guruş gazzanasın" (Yorgancıŏlu, 2006, s. 152-153) şeklinde geçen ifadelerden halk ekonomisinin etkin olarak var olduğu görülmektedir. Burada para kazanmak için çamaşır yıkayan, gergef işleyen masal karakterleri görülmektedir. Bu, halkın sosyal yaşamında ve kültüründe de olan halk ekonomisi unsurlarıdır. Anadolu masallarından "Yemen Padişahının Oğlu" (Sakaoğlu, 2002, s. 479-481) adlı masalda da Kıbrıs Türk masalına benzer olarak gergef işleme geçmektedir.

Her iki bölgenin masallarında halk ekonomisi unsurlarına rastlanmaktadır. Özellikle el sanatları ve zanaatları konusunda bir ortaklık görülmektedir.

\subsection{Meslekler}

Türk sosyal yaşamının önemli bir parçası olan meslekler usta-çırak ilişkisi, kullanılan aletler, üretim şekilleri ve geleneğiyle tarih boyunca kendine has bir kültür oluşturmuştur.

Anadolu Türk halk masallarında karşılaşılan meslekler ise şunlardır: Yaver, değirmenci, hekim, imam (hoca), uşak, aşçı, aşçı çırağı, lala, hancı, haremağası, kaptan, terzi, hizmetçi, halayık, cariye, çoban, fırıncı, bahçıvan. "Rüzgaroğlu" adlı masalda değirmenci şöyle yer almaktadır: Padişah, çocuklarının hayatını kurtaran, onlara kendi öz evladı gibi bakan değirmenciyi vezir tayin etmiş. Karısına fenalı yapmak isteyen başyaveri görevinden uzaklaştırıp kendisini memleketin dışına attırmış".

Kıbrıs Türk halk masallarında ise şu mesleklere rastlanmaktadır: Sünnetçi, süvari, çoban, mühdar (muhtar), hekim, imam (hoca), nişanc1, kaptan, çiftçi, dülger (marangoz), ebe, hancı, hizmetkar, defterdar, oduncu, yapıcı usdası, galfa. Örneğin; "Yemeyenin Yeyicisi Var" masalında kaptanlıktan şöyle bahsedilmektedir: "Gocası meşhur bir kapdanımış. Seferler yapar çok para gazanırmış" (Yorgancıoğlu, 2006, s. 37-39).

Her iki sahanın masallarına bakıldığında bugün devam eden veya günümüzde icra edilmeyen bazı geleneksel mesleklere yer verildiği görülmektedir. Bunun yanında günlük yaşamda yer bulan imam, aşçı, terzi, marangoz, fırıncı gibi mesleklere de yer verildiği görülmektedir. Türkiye ve Kıbrıs sahasında imam, hekim, kaptan, çoban vb. mesleklerin de ortak şekilde yer aldığı söylenebilir.

\subsection{Beslenme-Mutfak ve Kiler}

Mutfak kültürü, yemek yeme ve yeme-içme alışkanlıkları o kültürün yaşam şekillerini de ortaya koymaktadır. Mutfak kültürü denildiği zaman kullanılan malzemeler, bunların hazırlanması, pişirilmesi, saklanması, ikramı ve kullanılan araçgereçler anlaşılmaktadır. Türk mutfağında fasulye, nohut, mantı, çorba, ekmek, baklava, sütlü ürünler, şerbetler, pekmez, şalgam, kahve, ayran vb. daha birçoklarını sayabileceğimiz oldukça geniş bir mutfak kültürü vardır. 
Anadolu halk masallarında da mutfak kültürüyle ilgili unsurlarla karşılaşılmaktadır. Bunlardan ilki Kıbrıs Türk halk masallarında da önemli bir yeri olan kahvedir. "Üç Dokumacı Kardeş" masalında kahve "buyurun bizim fakirhaneye gidelim de bir acı kahvemizi için. Siz galiba yabancısınız. Bunları alıp evine götürür. Padişahın kızına: -Senin baban ne yemeğini çok sever? / -Benim babam baklavayı çok sever./ Ya senin baban neyi çok severdi?/ Kadayıfı" (Sakaoğlu, 2002, s. 347-350) şeklinde geçmektedir. Yine "Üç Dokumacı Kardeş", "Padişahlar Padişahı" ve "Güneş Kız" masallarında kahveden bahsedilmektedir. Örneğin, "Güneş Kız1" adlı masalda kahvenin "Bir gün gene ava çıkan oğlan, her zamanki avcılara rastlamış. Onları eve kahveye çağırmış. Kahveler içildikten sonra avcılar daha fazla kalmadan gitmişler" (Tezel, 1992, s. 9-29) şeklinde ifade edildiği görülmektedir. Kahve yanında örnekte dikkati çeken diğer Türk'e has yiyecekler de kadayıf ve baklavadır. "Padişahın Üç Kızı" masalında ise keşkek pişirmekten bahsedilmektedir (Alptekin, 2002, s. 241-247). Keşkek Kıbrıs masallarında herse olarak geçmektedir. "Güneş Kızı" masalında ceplere leblebi doldurulduğundan söz edilmektedir (Tezel, 1992, s. 9-29). "Hamamcı ile Keloğlan” adlı masalda tavuğu haşlayıp suyuna pilav yapmışlardır (Tezel, 1992, s. 154-162). Tavuk suyuna pilav da Türk kültüründe yaygın olarak yapılan bir yiyecektir ve Kıbrıs mutfak kültüründe de yeri olan bir yemektir. "Hanımından Gorkan Osman Ağa" masalında "ben bir pekmez gatayım yeyim. Pekmez tuluğunun bucağından gatmaya başlamış" şeklindeki cümlede pekmez görülmektedir (Alptekin, 2002, s. 238-240). "Sihirli Tavşan" masalında ise "Padişah, (sarayın bahçesindeki) elmayı her sene törenle kopartır, küçük küçük doğrattırarak hoşaf kaynattırır" cümlesinde hoşafa yer verildiği görülmektedir (Tezel, 1992, s. 49-69). "Tuz" adlı masalda da yiyeceklerden bal, börek ve kadayıftan bahsedilmektedir (Tezel, 1992, s. 94). "Doğruluk" adlı masalda ise bazlamaya değinilmiştir (Tezel, 1992, s. 123).

Kıbrıs Türk halk masallarında kültürel yiyecek-içecekler metinlerde oldukça fazla geçmektedir. Örneğin, "Deli Behlül'ün Aglı" masalında "Gocagarı daha tez gakıp bunnara bitta yapıp bişirdi. Birer tane yediler, birer tane da çıkınnarına goydu hem birer parça hellim" cümlesinde bitta (lavaş benzeri ekmek veya pita) ve hellim geçmektedir. "Ah dedi, usdamın gizzı buraşda olsa, bana bir gabbak şarab, şarabı içinca da bir şefdali verse" (Yorgancıoğlu, 2006, s. 27-30) şeklindeki cümlede de Kıbrıs Türk halk ekonomisinde önemli bir yeri olan şarap ile şeftali kebabı geçmektedir. Bitta, "Gecegezen" masalında da yer almaktadır: "Köyün en ucundaki evde oturan dul bir gocaman havlıda odun gırarmış. Ateş yakacakda bitta yabsın. Golay gelsin demiş, adama. Bu sahatte ne brakdın odun gırmayı? Napayım demiş adam, başga işlerinan oğraşdım. Yoruldum, acıgdım, şindi da yemek yapacam hem bitta da garnımı doyurayım" (Yorgancioğlu, 2006, s. 30-31). "Senin Kısmetin Budur" masalında ise "Bir gün kapuya bir tilenci gelir. Bu dul garı da bir parça egmeynan bir parça hellim verir" (Yorgancioğlu, 2006, s. 68-71) şeklindeki cümlede ekmek ve hellim geçmektedir. "Hellim peyniri, özellikle koyun sütünden ya da koyun sütü ile inek veya keçi sütü karışımından yapılabildiği gibi sadece inek sütünden de üretilebilen yarı sert, kabuksuz, elastik yapılı, gözenek içermeyen, beyaz-sarımtırak renkte, kendisine özgü karakteristik aromaya sahip bir peynirdir" (Gün ve Şimşek, 2011, s. 44). Ayrıca hellim Kıbrıs'ın önemli bir geçim kaynağı olarak da bilinmektedir. Kıbrıs Türk masallarında hellime sıkça yer verilmiştir. 
"Hakyemez Gardaşlar" masalında "Ben demiş böyü̈̆̈̈ isderim üç dane havuz olsun. Biri gonyak, biri şarap biri de zuk dolu olsun" cümlesinde konyak, şarap ve zuk (içki) geçerken masalın devamında ise Kıbrıs'a özgü kültürel bir yemek olan patates kebabı geçmektedir: "Çocuğu bazlamış, garısı da badadezleri soymuş. Furuna salmışlar iki sahat sora furunu aşma zaman gelir. Yabancı demiş gidin furunu açında herhalde kebap bişdi" (Yorgancıŏlu, 2006, s. 32-34) "Dinsizin Hakkından İmansız Gelir" masalında ise Kıbrıs Türk kültüründe ve sosyal yaşamında çok önemli bir yeri olan Türk kahvesi geçmektedir: "Gafe başga ingsan sıymaz. Mühdar demiş gafeciye evvela her birine bir gafe yap. Böyece gafeler benden" (Yorgancioğlu, 2006, s. 35-37). "Senin Kismetin Budur" masalında da kahve şöyle geçmektedir: "Ev saabı alır gadın içeri: -Hoşgeldin, der, gave yapar garşılıglı içeller" (Yorgancioğlu, 2006, s. 68-71).

"Yemeyenin Yeyicisi Var" masalında garayağ (zeytinyağı), badadez basdısı, fırın kebabı, ciğer kavurma, guru fasulye ve Kıbrıs'ta ovalarda yetişen ve yemeği yapılan hostes bitkisi (Yorgancioğlu, 2000, s. 65) şu şekilde geçmektedir: “Gadın hırsızlardan gorkduğu için küpün içindeki altınnarı görmesin diye küpü zeytiyağılyla doldurmuş.../ ...Birgün demiş adam garısına badedez gavirsın gendine.../ ...Bu gadar zenginig dururkan, bir okka et alıp kebap salacağına, badadez basdısı yapar, canı ciğercik çektiğinde bir ciğer alıp gavuracă̆ına da garı goca yesinner gider ovadan fosdes söker da basdırır. Bunu gören agrabaları bişey deyinca da hemen olmadık laflar eder. Siz bilmezsiniz der ă̆zınızın dadını. O fosdesler ciğercikdan da datlıdır. İki yumurta gara yağın içinde furun kebabından eyidir. Marahalı guru fasulye en eyi yemegdir" (Yorgancioğlu, 2006, s. 37-39). "Bir Çocuum Olsun Da İstersa İlan Olsun" (Yorgancioğlu, 2006, s. 42-47) adlı masalda da garayağ (zeytinyağı) geçmektedir.

Şerbet Kıbrıs Türk masallarından "Dilsiz Şahit" adlı masalda şu şekilde geçmektedir: "Nişannanmag içün neler lazım? Öngüne bir bendo lazım. Soora nişan urubaları, misafirlere datlı, içecek şerbet..." (Yorgancioğlu, 2006, s. 47-55). İncelenen Anadolu masallarında şerbete rastlanmamaktadır.

Kıbrıs yemek kültürüne özgü olan peksimet, herse (keşkek) ve bittaya "Uyuyan Güzel" masalında şöyle değinilmiştir: "Gardaşlarım açıkdı onnara da bidda bişirdim...Teyzesi evinden getirdiği unnarı yoğurur da peksimet yapar. Amma bassar içine duzzu, olullar lissa (çok tuzlu) /...Bana da bir tabag herse verdiler. Yeyib bitiremedim" (Yorgancıoğlu, 2006, s. 75-78). "Padişahınan Gızları" masalında da peksimet geçmektedir (Yorgancıoğlu, 2006, s. 87-89). Peksimet hamurdan yapılan bir tür susamlı sert çörektir (Yorgancioğlu, 2000, s. 60).

"Sihirli Tencere" adlı masalda ise geleneksel bir yiyecek olan püryan (Yorgancioğlu, 2000, s. 62) geçmektedir: "goymuş tencereyi drabezin üsdüne. Almış kapağ eline. Demiş gocagarıya söyle bakayım canın n'esder? Gocagarı da demiş püryan çekdi canım.../ ...almış tenceresini dönmüş evine. Garısı onu kapuda begler. Aldın tencerecii geri, aldım demiş ihtiyar de gene çıkardsın bir imambayıldı da aclıgdan nerdeysa bayılıyorum demiş gocagari. İki dane imam bayıldı çıkardmışlar sihirli tencereden, garnılarını doyurmuşlar" (Yorgancıoğlu, 2006, s. 113-115).

Kıbrıs ve Anadolu Türk halk masallarında yeme-içme kültürü bakımından birçok benzerlik olmakla birlikte bazı farklılıkların da olduğu masallardan tespit 
edilebilmektedir. Kıbrıs Türk mutfağında Anadolu mutfağında yer alan birçok yemek bulunurken bazı farklarla değişik yerel yiyeceklerin de olduğu görülmektedir.

\section{6. Ölçme-Tartma-Hesaplama Birimleri}

Günümüzde unutulmaya yüz tutmuş geleneksel ölçü ve tartılar da önemli halk bilgisi ürünlerindendir. Bilindiği gibi insanoğlu geçmişten günümüze nesneleri, mesafeleri vs. farklı şekillerde ve farklı materyallerle ölçmüş ve tartmıştır. Tabi ki bunlar, icatlar ve teknolojik gelişmelerle birlikte değişmiştir. İncelenen masallarda da geleneksel ölçme ve tartma bilgisine yer verilmiştir.

Anadolu masallarında çeşitli ölçü birimleri geçmektedir. Örneğin, "Güneş Kızı" masalında "birkaç arşın bez almış" (Tezel, 1992, s. 9-29) cümlesinde arşın ölçü birimi geçerken "Keloğlan Köse'ye Masalı" adlı masalda "altı batman buğday" (Tezel, 1992, s. 150-153) cümlesinde batman ölçü birimi geçmektedir. Yine "Kırk Oğlan" masalında "kırk kulaç derinliğindeki kuyu" (Tezel, 1992, s. 1-8) cümlesinde kulaç ölçü birimi geçmektedir.

Kıbrıs masallarında da çeşitli ölçü birimlerine rastlanmıştır. Örneğin; "Yemeyenin Yeyicisi Var" adlı masalda "okka et alıp, kebap salacağına badadez basdısı yapar" (Yorgancioğlu, 2006, s. 37-39) cümlesinde okka geçmektedir. "Sihirli Tencere" masalında da "gadın gomuşu köyleri dolaşmış, birkaç ogga un vermişler" (Yorgancıŏlu, 2006, s. 113-115) şeklinde okka geçmektedir. "Güvercin Şehzade" masalında da "çarşıdan iki arşın uruba almış" (Yorgancığlu, 2006, s. 152-153) cümlesinde arşın ölçüsü geçmektedir. Yine Anadolu Türk halk masallarında karşılaşılmayan tono tartı birimine Kıbrıs Türk halk masalı "Dilsiz Şahit" masalında yer verilmektedir.

Masallarda geçen ifadelerden anlaşıldığı üzere eski ve yeni ölçü birimlerine her iki ülkenin masallarında da yer verilmektedir.

\subsection{Giyim-Kuşam ve Süslenme}

Tarih boyunca Türk giyim-kuşam ve süslenme kültürü din-coğrafya gibi etkilerle oldukça fazla değişikliklere ve çeşitlenmelere uğramış, Orta Asya'dan Anadolu'ya ve oradan da Kıbrıs'a farklılaşmalar yaşamıştır. Bu eski ve derin kültür Anadolu ve Kıbrıs'ta zengin bir giyim-kuşam ve süslenme kültürü oluşturmuş ve bunlar masallara da yansımıştır.

İncelenen Anadolu Türk halk masallarında ince beyaz entari, tül elbise, demir elbise, ceket, sırma yelek, ipekli sultan elbisesi, beyaz kalpak, kuşak, altın nalın, altın kemer, yüzük gibi unsurlar geçmektedir. Örneğin, Anadolu Türk halk masallarından "Küllü Fatma" masalında "geyinmiş, guşanmış, getmiş ayağına da bir altın nalin geymiş, pırıl pırıl her tarafi, kemer altın, her şey altın." cümlesinde altın nalin ve altın kemer geçmektedir (Alptekin, 2002, s. 248-250). Yine "Kırk Haramiler" adlı masalda savaş giysi ve gereçlerinden demir elbise, demir miğfer geçmektedir: "Güzel sultan, hemen demir elbisesini giymiş. Başına demir miğferini geçirmiş. Sol eline demir kalkanını, să̆ eline de kılıcını almış". Aynı masalda geçen diğer cümledeyse elbise ve kalpak geçmektedir: "Bir gün, elbisesi gayet şık kumaşlardan yapılmış, beyaz kalpaklı yakışıklı bir delikanlı saraya gelmiş" (Tezel, 1992, s.102-122). 
Kıbrıs Türk halk masallarında ise parıldak babuç (parlak pabuç), ipekli entari, kırmızı entari, beyaz entari, tül elbise, çarşaf, gelinlik, pantolon, çember, yemeni, kavuk, kara potin, demir çarık, uzun çizme, mücevher gibi giyim-kuşam unsurları geçmektedir. Örneğin, Kıbrıs Türk halk masallarından "Padişahınan Gızlar" masalında demir çarık ve gelinlikten şöyle bahsedilmektedir: "Gız babasına der, yabdır bir demir çarıg. Bir yeşil, bir beyaz, bir da gırmızı gelinnig. Da gidecem bulayım gocamı" (Yorgancioğlu, 2006, s. 87-89). "Dilsiz Şahit" adlı masalda ise entari, etek, pabuç ve çember (yazma) geçmektedir: “Gız çeşmeye gider. Entarisini eteklerini çeker yokarı. Dizlerine gadar suyun içine goyar ayakların. Sora babuşların geyer, çemberinin uşların da arkaya atar", "Gız yemenisini düzeldip sol gulağnın üsdüne fiyong bağlar" (Yorgancioğlu, 2006, s. 47-55).

Her iki bölgenin masallarında demir çarık ve demir elbisenin yer alması dikkat çekicidir. Çünkü demir madeni ve demircilik Türk kültür tarihinde yer edinmiş olan, destanlarda ve halk inançlarında da geçen unsurlardır. Özellikle halk inançlarına bağlı uygulamalarda oldukça fazla yer bulan demir madeni makas, iğne, bıçak vb. şekillerde karşımıza çıkmaktadır. Bunun yanında Osmanlı dönemi giyim-kuşamının Anadolu ve Kıbrıs Türk halk masallarına yansıdığını da söylemek mümkündür.

\subsection{Halk Hekimliği}

Türk kültür tarihinde Şamanlarla başlayan sağaltma ve tedavi geleneği (Bayat 2006: 252-265) özellikle Anadolu'nun birçok bölgesinde halen devam etmekte ve masallarda da yerini almaktadır (Şimşek, 2001, s. 6).

Anadolu halk masallarından "Aslan Mehmet" adlı masalda çocuğu olmayan padişaha, derviş okunmuş elma verir, yarısını padişah, yarısını eşi yiyerek şifa bulur ve çocukları olur (Alptekin, 2002, s. 233-237). "Doğruluk" masalında "hekim hurma ağacından on, on beş kuru yaprak toplayıp avucunda ufalayıp hepsini toz haline getirmiş. Tozları bir kavanoza koymuş, hekim sultanın gözlerine tozdan serpmiş sonra eğilip üflemiş sultan görmeye başlamış" (Tezel, 1992, s. 123-139) şeklindeki ifadeler de doğrudan halk hekimliğini işaret eder niteliktedir.

Kıbrıs Türkleri arasında da 1900'lü yılların ortalarına kadar etkisini sürdüren sağaltma usulleri bugün modern yaşamın da etkisiyle uygulanırlığını yitirmiş gibidir. Ancak yine de bunlar eskiden beri anlatıla gelen masallarda yerlerini almışlardır. Örneğin "Sağır İlan Meseli" masalında "yılan zehrini delikanlının yaralarına sürüp iyileştirmiş" (Yorgancioğlu, 2006, s. 15-17) şeklinde bir sağaltma usulünden bahsedilmektedir. "Beddualı Çocuk" masalında ise "padişahın çocuğu olmuyormuş, vezirlerini yollamış araşdırsınnar nasıl çocuk olabilir. Vezirler bir periynan garşılaşmış. Peri vermiş bunnara bir elma, yarısımı padişah yeycek yarısını da garısı söylemiş da ortalıkdan gaybolmuş" (Yorgancioğlu, 2006, s. 23-25) şeklinde ifadeler geçmektedir.

Anadolu ve Kıbrıs Türk halk masallarında çocuksuzluk karşısında çare aranması ve çarenin elma yenilerek bulunması sıklıkla karşılaşılan bir durumdur. Türk halk hikâyelerinde de çocuksuzluk, çare arama ve Hızır-elma motiflerine rastlandığı bilinmektedir. İncelenen masallarda farklı şekillerde karşımıza çıksa da her iki bölge masallarında sağaltıcı işlemlere yer verilmesi ortak bir kültürün ifadesidir. 


\subsection{Halk İnançları, Töreler, Âdetler, Gelenekler-Görenekler}

Halk inançları animizm, totemizm, Şamanizm, dağ, su, ateş ve atalar kültü, Tengricilik gibi eski din ve inanç sistemlerinden beslenen ve çoğu zaman da âdetler, gelenekler ve göreneklerle bütünleşerek halk zihninde yer edinen kutsallardır. Bunlar dine benzer şekilde, inanan insan tarafından uyulması zorunlu hissedilen uygulama ve inanışlardır.

Anadolu Türk halk masallarından "Güneş Kızı" masalında "iki kardeş, gözleri yaşlı adamla kadının ellerini öpüp oradan ayrılmışlar" (Tezel, 1992, s. 9-29) şeklinde, "Limon Kız" masalında ise "dă̆ başında ihtiyar bir adama rastlamış selam vererek ihtiyar adamın elini öpmüş" (Tezel, 1992, s. 78-93) şeklinde el öpmeden bahsetmektedir. El öpme her iki ülkenin kültüründe de büyüklere saygı ve sevgi anlamını taşımaktadır. Eski çağlardan beri süregelen bir başka gelenek ise çeşitli amaçlarla kurban kesip kan akıtmaktır. Hem Anadolu hem Kıbrıs Türk halk masallarında kurban kesme geleneğine yer verilmiştir. Anadolu halk masallarından "Hanımından Korkan Osman Ağa" adlı masalda "Devler o şehirden suyu kesermiş, şehire vermezlermiş. O gün devlere verilecek olan gurbanlık giz o bölgenin beyininmiş. Sıra beyin gızına gelmiş." cümlesinde kurbanlık vermekten bahsedilmektedir (Alptekin, 2002, s. 238).

Kıbrıs Türk halk masallarında ise kurban kesme geleneğine şöyle yer verilir: "Hamarat Gadın ve Naletli Köprü" masalında "padişah yapıcı usdasını çă̆ırır. İsderim o derenin üsdüne üç kemerli bir köprü gurasın. Galfalardan biri usda başına demiş: -Her şey tamam ama temele gan akıtmayacağık?" (Yorgancığlu, 2006, s. 27-30). Kıbrıs'ta son yıllara kadar mevcut olan yeni yapılacak binanın temeline kan akıtma geleneği bu masalda karşımıza çıkmaktadır.

Kıbrıs Türk halk masallarından "Dilsiz Şahit" adlı masalda "çemberini uşdan uca gatlayıp ortalar, başına goyar da fiyongunu sol gulağının üsdüne bağlar" şeklinde bir gelenekten bahsedilmektedir. (Yorgancioğlu, 2006, s. 47-55). Yapılan bu uygulama eski Kıbrıs Türk kültüründe birinin aşkına düşmek manasına gelmektedir. El öpmeye hemen hemen bütün masallarda değinilmiştir. Örneğin; Kıbrıs Türk masalı olan "Beddualı Çocuk" adlı masalda "iznin olursa garımı da alı gideyim elini öpeyim, hayır duasını alayım" şeklinde geçmektedir. (Yorgancioğlu, 2006, s. 23-25). "Deli Behlül'ün Aglı" masalında ise "Gocagarinin elini öpüp hayır doasını aldıktan soora yola çıkdılar" (Yorgancioğlu, 2006, s. 27-30) şeklinde el öpme geleneğinden bahsedildiği gözlenmektedir. Başka bir inanç olan cemre düşmesi ise "İlahim Damın Agsın Da Gazanın Altına Saklasın" adlı Kıbrıs Türk halk masalında "mart ayının sonunda abril girince hem havaya hem toprağa cemre düşer" şeklinde ifade edilmiştir (Yorgancioğlu, 2006, s. 56-57).

Her iki sahadaki masallarda benzer olarak karşımıza çıkan el öpmenin bugün de yaygın olarak yaşayan bir görenek olduğu söylenebilir. Bunun yanında kurban kesme geleneği sosyal yaşamda hem Anadolu hem de Kıbrıs Türkleri arasında İslam dinine ve çeşitli inançlara bağlı olarak (ör. adak adama) halen daha devam etmektedir. 


\subsection{Geçiş Dönemleri}

\subsubsection{Doğum}

Türk kültüründe doğum soyun devamlılığı açısından çok önemli bir yere sahiptir. Türk destanlarından Dede Korkut'a ve halk hikâyelerine kadar birçok halk edebiyatı metninde yer alan çocuksuzluk ve doğum motifleri oldukça önemlidir ve sosyokültürel yaşamın tam ortasındadır. Çünkü Türk kültüründe soyun devamlılığında özellikle erkek çocuğun olması istenen bir durumdur. Tabi ki kız çocuğunun aile ve toplumdaki yeri de önemli ve saygındır. Masallarda da bu durum gözlemlenmektedir.

Anadolu Türk halk masallarından "Padişahınan Üç Kızı" masalında da kadının dualarla çok istediği çocuklarına kavuştuğu görülmektedir: "Kadının doğumunun yaklaştığı stralar seferberlik ilan oluyor. Padişah askerlerini çekip seferberliğe gediyor. Vaad işini ise annesine bırakıyor. Çocuklar dünyaya geliyor. Gadının duası aynen kabul oluyor. Bir gız bir oğlan saçları yıldız gibi parlıyor" (Alptekin, 2002, s. 242-247). "Aslan Mehmet" masalında da çocuğu olmayan padişah ve eşi, dervişin verdiği elma yardımıyla çocuk sahibi olur (Alptekin, 2002, s. 233).

Kıbrıs Türk halk masallarından "Bir Çocuğum Olsun da İsterse İlan Olsun" masalında yer alan "gadında inceden inceye sancılar başlamış. Gocasına söylemiş. Adam da bohcanı hazırla ben de ebeye haber vereyim demiş. Ebe gadını ilaçlayıp yatırmış. Dikkatlice incelemiş çocuğu. Soora bir kasede hazır ettiği şekerli suyu ağzına boşaltmış. Çocuk ağlamayı kesmiş. Onu duzlu suyla ikayıp duz göğneğini geydirmiş" (Yorgancioğlu, 2006, s. 42-47) şeklindeki anlatımdan kadının ne olursa olsun bir çocuk sahibi olmak istediği görülmektedir. Ayrıca yeni doğan çocuklara tuz gömleği giydirme geleneği de masalda geçen diğer bir doğum sonrası âdetidir (Mear, 1992, 32; Yorgancioğlu, 2000, 195). "Beddualı Çocuk" masalında ise "padişahın çocuğu olmuyormuş, vezirlerini yollamış araşdırsınnar nasıl çocuk olabilir. Vezirler bir periynan garşılaşmış. Peri vermiş bunnara bir elma, yarısını padişah yeycek yarısını da garısı söylemiş da ortalıkdan gaybolmuş." (Yorgancıŏlu, 2006, s. 23-25) şeklindeki ifadelerden dervişin yardımıyla çocuk sahibi olunduğu görülmektedir.

Doğum gelenekleri ile ilgili her iki bölgede de en çok dikkat çeken şey -halk hekimliği kısmında da değinilen- çocuksuzluk, çare arama ve doğum motifleridir. Anadolu ve Kıbrıs Türk sosyal yaşamında çocuk sahibi olamamak hoş karşılanmaz ve çocuksuz aile gizliden gizliye hor görülür. Nasıl ki Dirse Han Oğlu Boğaç Han hikâyesinde çocuksuz Dirse Han'a kara otă̆, kara keçe ve kara koyu yahnisi münasip görülmüşse toplumsal yapıda da bu hor görülme gizli de olsa devam etmektedir. Bu nedenle masallarda da bu olgunun bir yansıması olarak çocuksuzluğa çare arama karşımıza çıkmaktadır.

\subsubsection{Ad koyma}

Eski Türk geleneklerinde ad vermeye oldukça büyük önem verilmektedir (Turgunbayer, 2007). Bu durum somut olarak Dede Korkut Hikâyelerinde görülmektedir. İslamiyet'le birlikte halk edebiyatı metinlerinde ad vermeyi derviş, Hızır, pir gibi İslami karakterlerin gerçekleştirdiği görülmektedir. Halk edebiyatı 
metinlerinde (destan, halk hikâyesi) yer alan çocuksuzluk motifinde kahramanın olağanüstü doğumunda Aksakallı Dede, Derviş, pir veya Hızır'ın rol aldığı ve çocuğa ad vermede tekrar ortaya çıktığı bilinmektedir.

Anadolu Türk halk masallarından "Aslan Mehmet" isimli masalda İslami kültürün etkisiyle çocuğa adını derviş vermektedir. Bu durum masalda "Bir padişah varmış. Bu padişahın hiç çocuğu olmamış. Bir derviş varmış bir elmaya dua okumuş, üfürmüş. Bu elmanın yarısını sen yarsını da ailen yeyecek. Bi oğlunuz olacak, oğlanın adını da ben goyacağım demiş. Bi gün yemek yapmışlar. O gece de hemen derviş gelmiş. Derviş çocuğun ismini Aslan Mehmet goymuş" şeklinde geçmektedir (Alptekin, 2002, s. 233-237).

Kıbrıs Türk halk masallarından "Bir Çocuğum Olsun da İsterse İlan Olsun" masalında ise "ebe bebeğin adını Salih goymuş" şeklinde ifade edilmektedir (Yorgancığlu, 2006, s. 42-47). Kıbrıs Türk sosyokültürel hayatında ebelerin de bebeğe isim verdiği, ailenin bunu beğenmemesi üzerine ise tekrardan bir isim koyduğu bilinmektedir (Yorgancıŏlu, 2000, s. 200).

Çocuğun adının ebe veya derviş tarafından konulması aslında çocuğun adının başka biri tarafından verilmesine işaret eder. Bu gelenek her iki bölge masallarında da karşımıza çıkmaktadır.

\subsubsection{Sünnet}

Türk kültüründe çocukla ilgili dinsel ve geleneksel törenlerin en önemlilerinden biri de sünnettir. Anne babaların en önemli görevlerinden biri çocuğu sünnet ettirmesi ve evlendirmesidir. Sünnet Türk insanı açısından özel bir anlam ifade etmekte ve özellikle bazı bölgelerde yapılan ihtişamlı törenlerle coşku içerisinde kutlanmaktadır. Türklerin İslamiyet'i kabul etmeleriyle birlikte dinî bir unsur olarak kabul edilen sünnet, Türk kültür tarihi içerisinde de insan yaşamında geçiş dönemleri olarak (doğum, sünnet, evlenme ve ölüm) önemli yere sahiptir. İncelenen Anadolu Türk halk masallarında sünnet geleneğine rastlanmamıştır.

Kıbrıs Türk halk masallarından "Beddualı Çocuk" masalında sünnet, "padişah emretmiş hazırlıklar yapılsın da oğlunu sünnet edecek. Hafda başı düğ̈̈n dernek gurulu olsun, memleketin en namlı sünnetçisi da hazır olsun..." şeklinde geçmektedir (Yorgancıŏ̆lu, 2006, s. 23-25).

Türk kültüründe erkekliğe geçiş olarak değerlendirilen sünnet, Türkler arasında erkekler için son derece önemli bir evredir. Genellikle Türk kültüründe, İslam dininin bir gereği olarak kabul edilmesine rağmen yapılan sünnet törenleri aynı zamanda millî, unsurlar da içermektedir. Özellikle törenlerde yapılan yöresel oyunlar ve ikram edilen yiyecekler, sünnetin millî yönünü de ifade etmesi açısından son derece önemlidir. Söz konusu gelenek incelenen Kıbrıs Türk masallarında yukarıda ifade edilen şekilde karşımıza çıkarken, ele alınan Anadolu Türk halk masallarında sünnetle ilgili bir unsura rastlanmamıştır.

\subsubsection{Evlenme ve düğün}

Düğün geleneği evrensel olmakla beraber, bu amaç doğrultusunda izlenen yollardan biri olan kız isteme ve bu isteme sırasında yapılan birtakım uygulamalar Türklere özgü birtakım özellikleri içerisinde barındırmaktadır. Çünkü her halk dügün 
geleneğini ve gelenek çerçevesinde yapılan birtakım uygulamaları kendine özgü kurallar, sosyokültürel değerler etrafında sürdürmektedir.

2.10.4.1. Kız isteme: Türk kültüründe kız evine dünürcü gitme ve kız isteme âdetinin bulunduğu bilinmektedir. Genellikle evlenme çağına gelen oğullarına evleneceği kızı bulma ve onları evlendirme anne babanın görevidir.

"Güneş Kızı" isimli Anadolu Türk halk masalında kız isteme şu şekilde karşımıza çıkmaktadır: "Oğlan, atına atlayıp evine dönmüş, hemen anasının yanına çıkarak: -Anacı̆̆ım demiş, senden bir dileğim var. Çobanın küçük kızıyla evlenmek istiyorum. Çobanın evine giderek aile küçük kızı oğluna istemiş. Her iki aile de gençlerin evlenmelerini uygun gördüklerinden kısa zamanda düğ̈̈n yapılması kararlaştırılmış" (Tezel, 1992, s. 9-29). Türk kültüründe evlenecek olan gençlerin ailelerinin de evliliğe onay vermeleri önemli bir husustur. Bu durum ele alınan masala da yansımıştır.

"Senin Kısmetin Budur" isimli Kıbrıs Türk masalında da kız isteme âdetinden şu şekilde bahsedilmektedir: "Birgün bir deliganlı garar vermiş bunu isdetsin. Demiş anasına, Ana bana gide çubanın gizınis deyesin. Benim göynüm ona düşdü. Sen bana bu gizzı Allah'ın emrine isde. Gadın geyer çarşafinı, gider çubanın garısın kapusuna. Ev saabı alır bunu içeri. Gave yapar garşılıklı içeller. Gadın; -Bizim adamılan gelelim da ailece Allah'ın emrine gızzınızı isdeylim" der (Yorgancioğlu, 2006, s. 68-71).

Gerek Anadolu Türk halk masallarında gerekse Kıbrıs Türk halk masallarında kız isteme geleneğin aynı şekilde yer aldığı ve her iki ülkenin toplumsal yaşamında söz konusu geleneğin çok önemli bir yer tuttuğu görülmektedir.

2.10.4.2. Söz kesme: $\mathrm{K} 1 \mathrm{z}$ istemeye gidildiğinde ailelerin anlaşıp aralarında birbirlerine söz vermesi Türk kültüründe "söz kesme" olarak bilinmektedir.

Ele alınan "Güneş Kızı" masalında; "her iki aile de gençlerin evlenmelerini uygun gördüklerinden kısa zamanda düğün yapılması kararlaştırılmış. Söz kesilmiş" (Tezel, 1992, s. 9-29) şeklinde söz kesme geleneğinin vurgulandığı görülmektedir. Yine incelenen bir diğer masal olan "Padişahın Üç Kızı" isimli masalda da "padişah en böyük kıza bir düğ̈̈rrcü gönderiyor. Ondan sonra ortancaya düğ̈̈r gönderiyor. Onu da alıyor. Zaten onlar sözlü, bu işin çabuk biteceğini biliyor" (Alptekin, 2002, s. 241-247) şeklinde sözlenen çiftlerden bahsedilmiştir.

İncelenen Anadolu Türk halk masallarında "söz kesme" geleneği tespit edilirken, Kıbrıs Türk halk masallarında bu geleneğe rastlanmamıştır.

2.10.4.3. Nişan: Düğünden önceki ilk toplu kutlama olarak geçen nişan Türk kültüründe önemli bir yer tutar. Aile kurmaya giden yolda söz kesmeden sonra atılan önemli adım nişan geleneğidir. Söz konusu gelenek özellikle çiftlerin birbirlerini tanımaları açısından son derece önemli işleve sahiptir. Söz kesiminden hemen sonra aileler tarafından nişan tarihi belirlenir ve Türklerde var olan anlayışa göre bu dönem çok uzun tutulmadan evliliğe gidilir. Söz konusu gelenek her ülkenin masallarında yer almaktadir. 
"Güneş Kızı" isimli Anadolu Türk halk masalında "söz kesilmiş, nişan yapılmış. Hazırlıklar tamamlandıktan sonra da sıra düğüne gelmiş" (Tezel, 1992, s. 9-29) şeklinde nişan geleneğinden söz edilmektedir.

"Dilsiz Şahit" isimli Kıbrıs Türk halk masalında ise "nişannanmag içün neler lazım? Öngüne bir bendo lazım. Soora nişan urubaları, misafirlere dadtl, içecek şerbet... o insannarılan gonuşalım gün ayıralım da sizi nişannaylım" (Yorgancıŏlu, 2006, s. 47-55) gibi söylemlerle nişan geleneğinden ve bu gelenek için yapılan hazırlıklardan ayrıntılı bir şekilde bahsedilmektedir.

Anadolu ve Kıbrıs Türk halk masallarına bakıldığında nişan için ön hazırlık yapıldığ 1 görülmekte ve her iki kültürde de düğünden önce nişanın önemli bir yer tuttuğu anlaşılmaktadır.

2.10.4.4. Kına: Türk kültüründe en önemli geleneklerden bir tanesi de kına yakmaktır. Türklerde genel olarak Allah yoluna kurban edildiği için kesilecek kurbana, vatana kurban edildiğini ifade etmek için askere gidecek kişiye ve baba ocağından yeni evine gönderildiği için gelinlere olmak üzere üç olay için kına yakılmaktadır. Türklerde kına yakma aynı zamanda saflığın ve temizliğin işareti olduğundan kına geceleri bazı bölgelerde büyük eğlencelerle kutlanmaktadır.

"Küllü Fatma" isimli Anadolu Türk halk masalında "padişahın oğlunun düğünü varmış, kınaya çă̆ırmışlar. Doğru varmış kınada gardeşlerinin yanına oturmuş" şeklinde kınadan bahsedilmektedir (Alptekin, 2002, s. 248-250).

İnsan hayatında geçiş dönemlerinden biri olarak kabul edilen evlenme geleneği içerisinde kına uygulaması genel olarak değişimle birlikte Türk halkları arasında sürekliliğini devam ettirse de incelenen Kıbrıs Türk halk masallarında söz konusu uygulamaya rastlanmamiştır.

2.10.4.5. Nikah-dü̆̆̈̈̈n ve düğ̈̈̈n sonrası: Türk toplumunda aile en önemli kültürel unsurlardan biridir. Nikah ve düğün törenleri kişinin aile kurma aşamasında atmış olduğu adımlardan biridir. Yapılan nikah ve düğün törenlerinde gelen misafirlere çeşitli yemekler ve içecekler sunulmakta, bazı bölgelerde ise aynı zamanda o yöreye özgü oyunlar oynanmaktadır. Söz konusu nikah ve dügün törenleri özellikle kırsal kesimlerde aynı zamanda insanları kaynaştırıcı bir unsur olarak da dikkat çekmektedir.

Anadolu Türk halk masallarından "Gecegezen", "Yazılan Bozulmaz", "Üç Dokumacı Kardeş" adlı masallarda nikah geleneği tespit edilmiştir. Örneğin; Anadolu Türk halk masallarından olan "Üç Dokumacı Kardeş"te "Kardeşim der, ben ermiş bir adamım. Bu adam ile vakti saatimiz tamamland, evleneceğiz. Bizim nikahımızı sen kıy. Biz seni burada saklayacağız. Küçük kardeş onların nikahını kıyar, onları birbirine verir ve orada kalır" (Sakaoğlu, 2002, s. 347-350) şeklinde nikah geleneğinden söz edildiği görülmektedir.

Kıbrıs Türk masalı olan "Yazılan Bozulmaz" masalında "Adam Allah'ın emri peygamberin gavliyla gızınızı garılığa isderim, demiş. Tamam demiş adam. Madem da siz birbirinizi beğendiniz, bana da hayırlısı demek düşer, demiş. Oturup gün gararlaşdırmışlar. Nikah gıymışlar, düğ̈̈n derneg gurmuşlar" şeklinde hem kı isteme geleneğinden hem de nikahtan bahsedildiği görülmektedir (Yorgancioğlu, 2006, s. 39-42). 
Dügünler, Türk toplumunda aile kurmak için atılan ilk adım sayıldığından kutsal sayılmakta ve sosyokültürel yaşamın önemli bir unsuru sayılmaktadır. Soyun devamlılığını sağlama, eğlence ve bütünleştirme gibi özellikleri bulunan dügünler her iki kültürde de özel bir önem arz etmektedir. Anadolu ve Kıbrıs Türk halk masallarının hemen hemen tümünde kırk gün kırk gece düğün unsuru geçmektedir.

Anadolu Türk halk masallarından “Doğruluk”ta "padişahın emri üzerine, düğün hazırlıklarına başlanmış. Düğ̈̈̈n hazırlıkları bittikten sonra, kırk gün kırk gece süren şenliklerle iki gencin evlenmeleri kutlanmış" (Tezel, 1992, s. 123-139) şeklinde Türklerde düğün geleneği karşımıza çıkmaktadır. Yine "Kırk Haramiler" masalında da şenliklerle kutlanan bir düğün sahnesiyle karşılaşılmaktadır: "Padişahın emriyle hemen hazırlık başlamış. Hint şehzadesi ile padişahın biricik kızının evlenecekleri halka ilan edilmiş her tarafta şenlikler başlamış. Birçok padişahların ve şehzadelerin katıldıkları dü̈̆̈̈n kırk gün kırk gece görülmemiş eğlencelerle devam etmiş, kırk birinci günü Hint şehzadesi ile Bağdat'ın küçük sultanı evlenmişler" (Tezel, 1992, s. 102-122).

Kıbrıs Türk halk masallarından olan "Padişahınan Gızları" isimli masalda düğün "padişah emreder düğ̈̈̈ derneg gurulur, zornalar çalar davullara vurulur kırk gün kırk gece düğ̈̈n yapallar. Evleniller" (Yorgancıoğlu, 2006, s. 87-89) şeklinde geçmektedir. "Güvercin Şehzade" masalında da "oğlan gızzı bubasına tanışdırmış. Padişah da beğenmiş gızzı. Düğün dernek gurulmuş. Kırk gün kırk gece dü̆̆̈̈n yapmışlar. Ehaliyi yedirip içirmişler" (Yorgancioğlu, 2006, s. 153-155) şeklinde düğün geleneğine atıfta bulunulmuş ve Türk toplumunda bu eğlencelerin kırk gün kırk gece devam ettiğinin altı çizilmiştir.

Tespit edilen örneklerden hareketle Anadolu Türk halk masallarında ve Kıbrıs Tük halk masallarında düğünlerin benzer biçimde ve işlevde yer aldığı söylenebilir.

Dügün sonrası yapılan birtakım uygulamalardan olan, gerdeğe girme ve yüz görümlüğü düğünün önemli bir parçası olarak görülmektedir.

"Yazılan Bozulmaz" isimli Kıbrıs Türk halk masalında "Bunnar gerdeğe girmişler. Evlenmişler, mutlu olmuşlar" (Yorgancioğlu, 2006, s. 39-42) cümleleriyle dügüülerden sonra uygulanan gerdeğe girme âdetinden bahsedilmektedir.

İncelenen Anadolu Türk halk masallarında ise düğünlerden sonra yapılan gelenekler görülmemektedir.

\subsection{5. Ölüm- ölüm âdetleri}

Türk toplumlarında ölüm, uçmağa varmak olarak adlandırıldı. Ölümü, Tanrıya varmak olarak adlandıran Türkler, bunu normal bir olay olarak karşılamakta ve Allah'ın takdiri olduğunu kabul etmektedir.

Anadolu'ya ait olan "Avcr Ahmet" masalında "adam suyu gaynaddın mı kefeni hazırladın mı der. Gilıcı eline alır gadının kellesine bir gor, kellesi bir yanına geder. O suyunan onu yurlar, o kefine onu sorarlar, mezere gömerler" (Alptekin, 2002, s. 224-229) şeklinde ölümden söz edilirken, ölümden sonra tutulan yas ise "Küllü Fatma" adlı Anadolu Türk halk masalında şu şekilde tezahür etmiştir: "Annemin ölüsünü unutup da dü̈̆̈̈̈ne gitmem demiş" (Alptekin, 2002, s. 248-250). "Havva Hanım" masalında ise "Adam ölüyor. 
Adamın gırkı çıkar çıkmaz evleniyorlar." (Alptekin, 2002, s. 230-232) sözleriyle yine ölümden sonra yas tutulması gerektiğinin altı çizilmiştir.

"Yemeyenin Yeyicisi Var" adlı Kıbrıs Türk halk masalında ise "garısına geldi haber ki kaza oldu da öldü gocası. Gitmişler almışlar adamın ölüsünü da yıkayıp gömmüşler" cümleleriyle ölülerin gömülürken mutlaka yıkanması gerektiğinin altı çizilmiştir (Yorgancioğlu, 2006, s. 39-42).

Türklerde uzun zamandan beri devam eden ölü gömme âdetleri ve ölülerin ardından düzenlenen birtakım ritüellerin bugün de küçük değişiklerle bütün Türk toplumlarında devam ettiği bilinmektedir. Her iki ülkenin masallarında da söz konusu geleneğe benzer şekilde rastlanması bunun en açık göstergesidir.

\subsection{Misafirperverlik}

Türk kültüründe Türk'ün evine gelen misafir kutsal görülmektedir (Altunbay, 2016). Türk kültüründe ev sahipleri, evlerine gelen misafiri rahat ettirmek için büyük özen göstermektedirler.

Anadolu Türk halk masallarından "Avcı Ahmet" masalında çoban evine gelen misafire davar kesmektedir: "Çobanın yanına varır: "Çoban çoban!", "Eee, buyur", "Misafir alır mısın?", "Alırım gel bakalım, nerelisin sen?" (Alptekin, 2002, s. 224-229).

Kıbrıs Türk halk masallarından "Tembel Cingöz" masalında ise köye gelen adamın misafir edildiği görülmektedir: "Adam köyde istedi birkaç evde misafir galsın, akşam gecelesin, gabul ettiler" (Yorgancioğlu, 2006, s. 13-15).

Türk kültüründe tarih boyunca oldukça önemli bir yere sahip olan misafirperverlik hem Anadolu Türk halk masallarında hem de Kıbrıs Türk halk masallarında sıkça yer almaktadır.

\subsection{Dinsel-Büyüsel İnançlar ve Uygulamalar}

\subsection{1. İslamiyet}

İncelenen masallarda dinle ilgili namaz kılmak, cuma namazı, hacca gitmek, kurban kesmek, Kur'an okumak geçmektedir.

Anadolu Türk halk masallarından olan "Aslan Mehmet" masalında "yemeği yemişler Gur'an ve mevlüt okumuşlar" ifadesi bulunmaktadır. (Alptekin, 2002, s. 233-237). "Limon Kız" masalında "padişah ramazanda fakirlere yiyecek, bayramda giyecek dağıtırmış. Hayır duasını alırmış" (Tezel, 1992, s. 78-94) ifadeleri geçerken "Padişahın Üç Kızı" masalında ise "kıyamet günü ve mahşer yeri" ifadeleri geçmektedir (Alptekin, 2002, s. 241-247). "Küllü Fatma" masalında "abdest almak, namaz kılmak" (Tezel, 1992, s. 154162), "Kırk Oğlan" (Tezel, 1992, s. 1-8) masalında yine dinî terim olan "cehennem" görülmekte ve genel olarak masallarda sıkça "Hızır", "derviş", "Kevser suyu", "Allah senden razı olsun", "seni Allah gönderdi", "Allah'a şükretmek", "Allah yolunu açık etsin" gibi deyim ve sözlere yer verilmektedir.

Kıbrıs Türk halk masallarından biri olan "Yazılan Bozulmaz" adlı masalda "Ben gader meleğiyim, insanı insana yazarım oğlum demiş." gibi ifadeler görülürken, yine aynı masalda Müslümanlar için cuma gününün önemine vurgu yapılmıştır: "Cuma günü öğlen namazından sonra gel." "Yemeyenin Yeyicisi Var" (Yorgancioğlu, 2006, s. 37-39) 
masalında ise hacca giden kadının salgın hastalığa yakalanarak vefat ettiği görülmektedir.

Anadolu Türk halk masallarında ve Kıbrıs Türk halk masallarında din açısından temel farklılıklardan biri Kıbrıs Türk halk masallarında Rum kültürünün etkisiyle Hristiyanlık unsurlarının (papaz, haç/istavroz) da yoğun olarak bulunmasıdır. Sakaoğlu da çalışmasında benzer bir şekilde Kıbrıs Türk masallarında papaz tipinin Anadolu masallarından farklı olarak yer aldığını belirtmektedir (Sakaoğlu, 1983, s. 165). Bununla birlikte incelenen metinlerden hareketle Kıbrıs Türk halk masallarında İslami unsurların, Anadolu Türk halk masallarına göre daha fazla olduğunu söylemek mümkündür.

\subsubsection{Fal, rüya yorumu, gelecekten haber verme}

Geçmişten günümüze fal, falcılık, rüya, rüya yorumu Türk toplumlarında önemli bir uygulama alanıdır. Özellikle fal-falcılık geleneklerinin çok derin ve farklı kökleri vardır. İslam öncesi Araplarda falcılık bir ilim kabul edilirdi. İslamiyet'le birlikte kısmen önemi azalmış olsa da halen fal ve rüya yorumlarına önem veren birçok insan bulunmaktadır (Ertaylan, 1951, s. 1).

İncelenen Anadolu Türk halk masalları arasında fal ve rüya yorumuna rastlanmamıştır.

Ele alınan Kıbrıs Türk halk masallarında önemli işlerden önce fal baktırma ve rüya yorumlatma geleneğinin yer aldığı görülmektedir. Örneğin "Padişahınan Gızları" masalında "Padişah çă̆ırmış falcısını demiş gene yorumlasın bu durumu. Falcı demiş gene Bir taykada yorum olmaz. Padişahım bana üş gün müsade, istihareye yatacam. O gece rüyasında görmüş..." şeklinde bir ifade geçmekte ve falcının istihareye yatarak rüyasında gereken cevabı bulduğu görülmektedir. "Senin Kısmetin Budur" masalında ise "Çalgıcılardan bir çingane garısı eyi bir falcıymış. Uzad elini hadi nazlanma bakayım falına demiş." (Yorgancıoğlu, 2006, s. 68-71) sözleriyle fal baktırma ifadelerine yer verilmektedir. Burada falcı, kadına kiminle evleneceğini ve kaç çocuğu olacağını bildirmiştir. "Yemeyenin Yeyicisi Var" (Yorgancığlu, 2006, s. 37-39) masalında da rüya kavramına yer verildiği görülmektedir.

İnsanlık tarihinde geleceğin merak edilmesi ya da gelecekte olacakların önceden bilinmek istenmesi kişiler tarafından sürekli arzu edilen bir durumdur. Eski Türk kültüründe Şaman adı verilen kişilerin aynı zamanda gelecekten haber verme gibi bir işlevi de yerine getirdikleri bu bağlamda toplum tarafından saygı gördükleri bilinen bir durumdur. İslamiyet'in kabulü ile birlikte gelecekten haber verme görevini Türklerde falcılar üstlenmiştir. İncelenen Kıbrıs Türk halk masallarında yukarıda görüldüğü gibi bu husus sıkça geçerken, Anadolu Türk halk masallarında falcılığa ve rüya yorumuna rastlanmamıştır.

\subsubsection{Büyücülük}

İnsanlığın var oluşundan itibaren kişilerin yaşamında çok önemli bir yer tutan büyü ve büyücülük Türk toplumunda da özellikle bazı bölgelerde yaygın bir uygulama olmuştur. 
İncelenen Anadolu Türk halk masallarında büyü ile ilgili herhangi bir unsura rastlanmamıştır.

Kıbrıs Türk halk masallarından olan "Güvercin Şehzade" masalında üvey ananın bir büyücü olduğu görülmektedir: "Evey anam bir büyücü gadındır. Beni isdemediği için bana bir büyü yapdl. Başıma bu toplu iğneyi sokdu da beni bir güvercin yapdi. Sen onu çıkarınca büyü bozuldu" (Yorgancığlu, 2006, s. 152-153). "Padişahınan Gızları" (Yorgancıoğlu, 2006, s. 87-89) masalında ise sihir yapıldığı ve boynuzun içinden yakışıklı bir adam çıktığı görülmektedir.

Özellikle bilimin gelişmediği eski toplumlarda büyünün önemli bir olgu olarak toplumsal yaşama yön verdiği bilinmektedir. Ele alınan Anadolu Türk halk masallarında büyü ile ilgili herhangi bir unsura rastlanmazken, Kıbrıs Türk halk masallarında söz konusu unsura yer verildiği görülmektedir.

\subsection{Halk Edebiyatı}

Türk kültürünün ve sosyal hayatının önemli unsurlarından biri de halkın duygu ve düşüncelerini yansıtan halk edebiyatı ürünleridir.

"Padişahlar Padişahı" adlı Anadolu Türk halk masalında bir mâni yer almaktadır: "Zevku sefa kahve tütün, / Keyifler büsbütün, / Demden gelir, zır zır gider, / Bir cigara, sert tütün..." (Sakaoğlu, 2002, s. 351-355).

"Padişahısan Herşeyi Bilemen Ya" masalında toplumun duygularını yansıtmada çok önemli bir tür olan türkü, şu şekilde karşımıza çıkmaktadır: "Orak biçen adam gızzıl güneşin altında çalışır durmadan türkü söyler, gazel okur. Yola düşdüğ̈̈nda da türküler dördüsdünde" (Yorgancioğlu, 2006, s. 71-74).

"Hamarat Gadın ve Naletli Köprü" isimli masalda ise, "Gadın hem oynar hem gelir. Hem gelir hem da bir tekerleme söyler; Neden çă̆ırdı beyim /Başga nere gideyim? / Ellerimde altın top / Hop hop eder yüreğim" şeklinde bir tekerleme bulunduğu görülmektedir. Aynı masalda ayrıca bir de kargış bulunmaktadır. Kadın, kendisini kuyuya kurban veren kocasına şöyle beddua eder: "Dilerim Allah'ımdan benim gibin olursun/Bu bana yabdığım bir gün sen da bulursun. / Benim soyumdan olan, köprüden gelsin geçsin, /Ganını daşıyanlar, hepsi düşsün boğulsun...!" (Yorgancioğlu, 2006, s. 149-151).

Halk edebiyatının önemli bir kısmını oluşturan sözlü kültür ürünleri, Türklügün ve İslamiyet'in yayılmasında çok önemli bir rol oynamışlardır. Tarihî ve sosyal özellikleri açısından içerisinde birçok önemli unsuru barındıran mâni, türkü, tekerleme gibi sözlü kültür ürünleri, aynı zamanda Türklerin yaşam biçimini, dünyaya ve olaylara bakışını gösteren önemli kaynaklardır. Her iki ülkenin masallarında da bahsi geçen sözlü kültür ürünlerine yer verildiği görülmektedir.

\subsection{Halk Sporları}

Halk sporları eski tarihlerden beri tüm Türk dünyasında var olan kültürel değerlerdendir (Gül vd., 2018). Geçmişten günümüze özellikle Orta Asya'da yaşamını sürdüren Türkler, sporu bir eğlence aracı görerek; cirit, gökbörü, okçuluk ve güreş gibi alanlarda kendilerini geliştirmişlerdir. Geçmişte atın da eğitilmesiyle birlikte avcılıkla 
geçimlerini sürdürebilmek için kendilerini okçuluk alanında geliştiren Türkler, günümüzde bu tür halk sporlarını daha çok eğlence amaçlı sürdürmektedirler.

En bilinen Türk halk sporlarından biri olan cirit "Aslan Mehmet" isimli Anadolu Türk halk masalında şu şekilde karşımıza çıkmaktadır: "Çocuk atını düzmüş, her şeylerini terkisine goymuş, parasını pulunu her şeyini goymuş. Annesini terkisine almış atılan iki üç defa getmiş gelmiş. Yani cirit oynamış. At, çok dehşetli bir atmış" (Alptekin, 2002, s. 233237). "Kırk Oğlan" isimli Anadolu Türk halk masalında ise "dü̈̆̈̈n hazırlikları bittikten sonra ziyafetler verilmiş, eğlenceler yapılmış, pehlivanlar güreşmiş" şeklinde halk sporlarından olan güreşe yer verilmiştir (Tezel, 1992, s. 1-8). "Güneş Kız1" adlı Anadolu Türk halk masalında ok fırlatma oyunu ise şöyle geçmektedir: "Oğlan meydanda birkaç kişinin toplanıp bir şeyler yaptıklarını görmüşs. Merakla yanlarına yaklaşarak bakmış ki, bunlar, ellerindeki okları atarak karşıdakini kavak ă̆acını tepesinden aşırmaya çalışıyorlar. Fakat hiçbiri de okunu kavaktan aşıramıyormuş. Oğlan bunlardan birinin yanına yanaşarak arkadaş, şu okunu ver de şansımı bir de ben deneyeyim demiş. Oku vermişler. Oğlan ilk atışta oku kavaktan aşırmış" (Tezel, 1992, s. 9-29). "Sihirli Tavşan" masalında da yine okçuluk sporu görülmektedir (Tezel, 1992, s. 49-69).

İncelenen Kıbrıs Türk halk masallarında, özellikle Orta Asya'da yaşamını sürdüren Türk toplumlarında yaygın bir şekilde oynanan cirit, ok atma, güreş gibi halk sporlarına rastlanmamıştır.

\subsection{5. Çocuk Oyunları}

Oyunlar, çocukların fiziksel, duygusal ve zihinsel gelişimleri açısından son derece önemli bir yere sahiptir. Çocukların duygusal ihtiyaçları içerisinde yer alan oyunlar aynı zamanda birtakım kültürel değerlerin de gelecek nesillere aktarılmasında önemli bir işlevi yerine getirmektedirler.

"Padişahınan Gızları" masalında Kıbrıs'ın kültürünü yansıtan lingri isimli geleneksel çocuk oyunundan şu şekilde söz edilmektedir: "Biri lingriye hızl vurdu, gitdi gökyüzüne gayboldu. Bakannar göremedi, arayannar bulamadı. Meğer lingri gitmiş bir sarayın havlısına düşmüş... lingri yere çakılmış odların arasına. Bir ucu yokarı doğru dikili galmış" (Yorgancioğlu, 2006, s. 87-89).

Lingri oyunu Türkiye'de oynanan çelik çomak oyununun bir benzeridir. Ancak incelenen Anadolu Türk halk masallarında çelik-çomak oyununa veya herhangi bir çocuk oyununa rastlanılmamıştır.

Çocukların hayata hazırlanmalarında, sorunlarını çözmede ve birtakım beceriler kazanmalarında etkili olan oyunlar aynı zamanda onların çevrelerine ve kendilerine olan güvenlerini geliştirmelerine de katkı sağlarlar. Ele alınan metinlerden "Padişahınan Gızları" adlı masalda özellikle geçmişte Kıbrıs Türk çocuklarının yaygın bir şekilde oynadığı geleneksel lingri oyununa yer verildiği görülürken, Anadolu Türk halk masallarında çocuk oyunu tespit edilememiştir.

\subsection{Taşıtlar- Taşıma Teknikleri}

“1960’lı yıllarda Türklerde genellikle taşıma aracı olarak; at, deve, eşek, katır gibi hayvanların kullanıldığı görülmektedir. Bu taşıma vasıtaları zamanla yerini motorlu araçlara bırakmıştır" (Yeniasır ve Gökbulut, 2017, s. 500). 
"Padişahlar Padişahı" isimli Anadolu Türk halk masalında; 'vapura bindirin', 'vapura yolcu olur', 'vapura biner', 'vapur kalkacağı sırada', 'vapur yola çıkar' (Sakaoğlu, 2002, s. 351-355) ifadeleri geçmektedir. Yine Anadolu Türk halk masallarından "Altın Araba"da padişah, kıza kasabadaki okulu gidip gelirken binmesi için altın işlemeli bir at arabası armağan etmiştir (Tezel, 1992, s. 30-36).

"Yemeyenin Yeyicisi Var" isimli Kıbrıs Türk halk masalında da "almış hasda gızı binmiş bir eşeğin sırtına dutmuş hekimlerin yolunu" ifadesi bulunmaktadır.

Eşek, özellikle geçmişte yük taşıma amacıyla Türkler arasında sık kullanılan bir hayvandı. İncelenen Anadolu Türk halk masallarından birinde de "eşek semeri" ibaresi geçmektedir (Tezel, 1992, s. 150-153)

\subsection{Halk Sanatları ve Zanaatları}

Geçmişten günümüze insanoğlu, bazı ihtiyaçlarını karşılamak için farklı halk sanatları ve zanaatlarıyla uğraşa gelmiştir. Aynı zamanda kültürel şartlara bağlı olarak değişimler gösteren halk sanatları ve zanaatları, içerisinde doğmuş olduğu toplumun sanata olan bakış açısının da yansımasıdır.

"Güneş Kızı" adlı Anadolu Türk halk masalında yer alan şu ifadelerde el işi, işlemeli peşkirler geçmektedir: "Kız bezden güzel peşkirler yapmıฺ̧, üzerlerine iş işlemiş. Babaları da klzın yaptığı bu güzel peşkirleri pazara götürmüş. Halk bunları çok beğenmiş̧" (Tezel, 1992, s. 9-29).

"Senin Kısmetin Budur" isimli Kıbrıs Türk halk masalında "oğlan zenaat öğrenmiş, dülger olmuş" (Yorgancıoğlu, 2006, s. 68-71) ifadesi ile dülgerlik (marangozluk) zanaatına vurgu yapılmıştır.

Bununla birlikte incelenen Anadolu Türk halk masallarında halı-kilim dokuma, gergef işleme, altın gümüş kakma, altın gümüş işlemeli silah, sedef sandık, altın işlemeli kafes gibi sanat ve zanaatlar geçerken; Kıbrıs Türk halk masallarında da sepet, bendo (altın işi), gergef işleme gibi sanat ve zanaatlara yer verilmiştir.

Gergef işleme sanatıın hem Anadolu Türk halk masallarında hem de Kıbrıs Türk halk masallarında benzer şekilde yer aldığı tespit edilmiştir.

\section{DEĞERLENDIRME}

Makalede kültürün çok çeşitli alanları çalışmaya dahil edilmiş ve mekânlar, ev eşyaları, ekonomi türleri, halk ekonomisi, meslek, beslenme-mutfak ve kiler, ölçmetartma-hesaplama birimleri, giyim-kuşam ve süs, halk hekimliği, halk inançları; töreler, âdetler, gelenekler-görenekler, geçiş dönemleri, misafirperverlik, dinsel-büyüsel inançlar, uygulamalar, halk edebiyatı, halk sporları, yetişkin ve çocuk oyunları, taşıtlar-taşıma teknikleri, halk sanatları ve zanaatları ile ilgili tespitler yapılarak çıarımlarda bulunulmuştur.

Konak ve han her iki ülkenin masallarında da yer alan ve eski Osmanlı coğrafyasından kaynaklı kültürel mekânlardır. Konak ve han her iki ülkenin masallarında yer alırken, aşevine Anadolu Türk halk masallarında, hamama ise Kıbrıs Türk halk masallarında rastlanılmamıştır. Kuyu ve mağara ise diğer mekânlardan farklı olarak içeriğinde daha derin inanışlar, gelenekler, anlayışlar barındıran yer 
altıyla bağlantılı iki mekândır. Her iki ülkenin masallarında da masal karakterlerinin başına kötülük getirilmesi amacıyla söz konusu mekânlar metinlerde yer almaktadır.

Çalışmadaki ikinci başlık olan ev eşyalarında Anadolu ve Kıbrıs sosyokültürel yaşamında yer almış ve kullanılmış çeşitli eşyalar değerlendirilmiş ve her iki ülke masallarında çeşitli eşyalara yer verildiği görülmüştür. Bu başlıkta incelenen ocak kavramı da eski Türk kültüründe derin kökleri ve anlamları olan ve saygı duyulan bir unsurdur. Hem Anadolu hem Kıbrıs Türk halk masallarında ocağa yer verilmiş ve ocağın evde ayrı bir yeri olduğu anlatılarda sezdirilmiştir.

Ekonomi türleri başlığında eski Türk sosyokültürel hayatında ve destanlarında önemli bir yer tutan avcılık kültürü dikkat çekmektedir. Türk destanlarında hanların ve beylerin atları, tazıları ve kartallarıyla ava çıktıkları, ok kullandıkları bilinmektedir. Anadolu Türk halk masallarında tespit edilen av motifinde de ok ve av köpeği bulunduğu ve buna ek olarak tüfeğin de metinlerde yer aldığı görülmüştür. Ancak Kıbrıs Türk halk masallarında geleneksel avcılıkta kullanılan hayvan ve aletlerin geçmediği görülmüştür. Buna ek olarak Anadolu'dan farklı olarak ada ve deniz kültürünün de etkisiyle balıkçılığın da Kıbrıs Türk halk masallarında geçtiği görülmüştür.

Anadolu ve Kıbrıs Türk halk masallarında toplumun çeşitli sınıflarından meslekler bulunduğu görülmüştür. Kıbrıs'tan farklı olarak Anadolu Türk halk masallarında saray (hanedan) çevresinden meslek isimlerinin daha fazla yer aldığı tespit edilmiştir.

Beslenme-mutfak ve kiler başlığında her iki ülkenin mutfağıyla alakalı unsurlara yer verilmiş ve özellikle masalların ait olduğu kültüre has yiyeceklerden bahsedilmiştir. Buradan çıkan sonuca göre Kıbrıs ve Anadolu Türk halk masallarında mutfak kültürü açısından benzerlikler bulunmakta ancak iki ülkenin mutfağı farklılıkları da barındırmaktadır. Bunun yanında incelenen masallarda Kıbrıs Türk halk masallarının özellikle geleneksel mutfak ve kiler kültürüyle ilgili daha fazla unsuru barındırdığı söylenebilir.

Kültürün bir parçası olan ölçü-tartı birimlerine de masallarda yer verildiği gözlemlenmiştir. Her iki ülkenin halk masalarında ortak olarak geçen ölçü birimi arşındır. Anadolu Türk halk masalarında batman ve kulaç ölçü birimlerine incelenen Kıbrıs Türk halk masallarında rastlanmazken; okka, tono tartı birimine de incelenen Anadolu Türk halk masallarında rastlanmamıştır.

Sosyokültürel yapının önemli taraflarından biri olan giyim-kuşam ve takılarla ilgili de her iki ülke masallarında çeşitli unsurlar bulunmaktadır. Kıbrıs Türk halk masallarında pabuç, entari, elbise, çarşaf, gelinlik, pantolon, çember, yemeni, kavuk, potin, demir çarık, çizme, mücevher gibi giyim-kuşam unsurları geçerken; Anadolu Türk halk masallarında entari, elbise, demir elbise, ceket, sırma yelek, ipekli sultan elbisesi, kalpak, kuşak, altın nalın, altın kemer ve yüzük geçmektedir.

Kıbrıs Türk halk masallarında bulunan çarşaf, pabuç, potin, yemeni ve çembere Anadolu Türk halk masallarında yer verilmediği görülmüştür. Yine Anadolu Türk halk masallarında geçen nalın, demir elbiseye ise Kıbrıs Türk halk masallarında yer verilmemiştir. 
Tarih boyunca Türk giyim-kuşam ve takı kültürü din-coğrafya gibi etkilerle oldukça fazla değişikliklere ve çeşitlenmelere uğramış, Orta Asya'dan Anadolu'ya ve Kıbrıs'a gelene kadar bu anlamda birçok farklılık ortaya çıkmıştır. Bu eski ve derin kültür, Anadolu ve Kıbrıs'ta zengin bir giyim-kuşam ve süslenme kültürü oluşturmuş ve ortaya çıkan bu zenginlik masallara da yansımıştır.

Kökenleri eski Türk inanış ve uygulamalarına kadar dayanan ve her iki ülkede de uygulamaları yapılan halk hekimliğine her iki ülkenin masallarında da yer verilmiştir. İki ülkenin masallarında benzer olarak geçen sağaltma yöntemi, derviş-pirin verdiği elma yardımıyla kadınların iyileşerek çocuk sahibi olmalarıdır. Anadolu ve Kıbrıs Türk halk masallarında halk hekimliği ile ilgili farklı uygulamalar dikkat çekmiştir. Örneğin; Kıbrıs Türk halk masallarında yılan zehri, delikanlının yaralarına sürülüp onu iyileştirirken Anadolu Türk halk masallarında hekim hurma ağacından on, on beş kuru yaprak toplayıp avucunda ufalayıp hepsini toz haline getirir, tozları bir kavanoza koyar ve daha sonra sultanın gözlerine serper, bunun sonucunda sultan görmeye başlar.

Halk inançları, töreler, âdetler, gelenekler-görenekler başlığında her iki bölgenin masalarında el öpmenin saygı anlamında yer aldığı görülmektedir. Kurban kesme âdeti ise sadece Kıbrıs Türk halk masallarında geçmektedir. Kıbrıs Türk halk masallarında geçen yazmayı ortadan katlayıp başına koyarak bağlanma noktasını sol kulak üstüne getirme (birinin aşkına düşmek manasında) âdeti Anadolu Türk halk masallarında geçmemektir.

Her iki kültürde de önemli yer tutan geçiş dönemleri (doğum, çocukluk, evlenme ve ölüm) masal metinlerinde de yer bulmuştur. Doğumla ilgili dikkat çeken bir benzerlik her iki ülkenin masallarında da çocuk sahibi olmaya önem verildiğidir. Çocuğun cinsiyeti her iki ülkede de önemli değildir ve hem erkek hem kız çocuğu onay görmektedir. Doğumla ilgili geleneklerde özellikle Kıbrıs Türk halk masallarında yer alan bebeğe tuz gömleği giydirme geleneği Kıbrıs Türklerinin yaşamında uzun yıllar yer etmiş bir gelenektir. Buna benzer bir geleneğe Anadolu Türk halk masallarında rastlanılmamıştır. Türk halk hikâyelerinde ve destanlarında önemli bir yer tutan çocuksuzluk, çare arama, dervişin elma vermesiyle hamile kalma ve dervişin çocuğa ad vermesi motiflerinin Anadolu Türk halk masallarında yer aldığ1 görülmüştür. Kıbrıs Türk halk masallarında ise çocuksuzluk, çare arama ve doğum motiflerine yer verilmiş ancak ad verme motifi tespit edilmemiştir. Çocukluk döneminin önemli olaylarından sünnete Kıbrıs Türk masallarında rastlanırken Anadolu Türk halk masallarında rastlanılmamıştır.

Türk kültüründe çok önemli bir yere sahip olan misafirperverlik geleneği hem Anadolu hem de Kıbrıs Türk halk masallarında geçmektedir. Misafirperverlik Türk sosyal hayatında bir yaşam tarzı haline geldiği için destanlarda, halk hikâyelerinde ve masallarda da yerini almıştır.

İncelenen masallardaki dinsel-büyüsel inanışlara bakıldığında ise İslamiyet, büyü, fal ve rüya yorumlarıyla karşılaşılmaktadır. Masallardaki İslami unsurlara bakıldığında Kıbrıs Türk halk masallarında bu anlamda çok fazla unsurun yer aldığı görülürken Anadolu Türk halk masallarında bu oranın daha düşük olduğu tespit 
edilmiştir. Bugünkü sosyal yaşamda Kıbrıs Türkleri arasında çok katı bir İslami tavrın olmadığı düşünülürse söz konusu unsurların masallara yansımasının Kıbrıslı Türklerin Rum ve İngiliz baskılarına karşı bir kimlik oluşturma kaygısı olarak değerlendirilebilir. Çünkü İngilizlerin adayı sömürgesi altına aldığı dönemde Rumlar ve İngilizler, Kıbrıslı Türklerin hem dinine hem kültürüne hem de dillerine müdahalede bulunmaya çalışmışlar ancak bunda başarılı olamamışlardır. Ancak yine de kültürel etkileşimden dolayı Anadolu Türk halk masallarında rastlanmayan Hristiyanlıkla ilgili unsurlara Kıbrıs Türk halk masallarında rastlanılmıştır. Bununla birlikte büyü, rüya yorumu ve falcılık Kıbrıs Türk halk masallarında yer alırken Anadolu Türk halk masallarında söz konusu unsurlara yer verilmediği görülmektedir.

Halk edebiyatıyla ilgili olarak Kıbrıs Türk halk masallarında türkü, tekerleme ve kargışa yer verilirken Anadolu Türk halk masallarında maniye yer verilmiştir. Bunların yanında her iki ülkenin masallarında giriş, geçiş ve bitiş tekerlemelerine (formellerine) yer verildiği görülmektedir.

Halk sporlarına bakıldığında Anadolu Türk halk masallarında cirit, güreş ve ok fırlatmaya yer verilirken Kıbrıs Türk halk masallarında bu anlamda herhangi bir spor faaliyetine rastlanmamıştır.

Çocuk oyunları Türk kültüründe geçmişten beri var olup gelen bir gelenektir. İncelenen Kıbrıs Türk halk masallarında lingiri (çelik çomak) oyununa rastlanırken Anadolu Türk halk masallarında herhangi bir çocuk oyununa rastlanmamıştır. Günümüzde teknolojinin ilerlemesiyle birlikte özellikle geleneksel çocuk oyunlarının hem Türkiye hem de Kıbrıs'ta pek fazla oynanmadığı bilinmektedir.

Taşıtlar ve taşıma teknikleri ile ilgili hem modern hem de eski taşımacılık unsurlarının masallarda yer aldığı görülmektedir. Anadolu Türk halk masallarında at arabası dikkat çekerken Kıbrıs Türk halk masallarında ise ulaşımın daha çok eşekle yapıldığı görülmektedir. Kıbrıs'tan farklı olarak Anadolu Türk halk masallarında vapurla ilgili ifadeler de bulunmaktadır.

Halk sanatları bağlamında her iki bölgenin masallarında gergef işleme sanatının geçtiği görülmektedir. Bu bağlamda iki bölgenin masallarındaki farklara bakıldığında ise Kıbrıs Türk halk masallarında dülgerlik, sepet, bendo (altın işi) gibi sanat ve zanaatların bulunduğu, Anadolu Türk halk masallarında ise deriden kürk yapma, halıkilim dokuma, altın gümüş kakma, altın gümüş işlemeli silah, sedef sandık, altın işlemeli kafes gibi halk sanat ve zanaatlarının yer aldığı görülmektedir.

\section{SONUÇ}

Anadolu ve Kıbrıs Türk halk masallarının kültürel açıdan irdelendiği ve yorumlandığı çalışmada önemli ve ilginç sonuçlar elde edilmiştir.

Görüldüğü üzere Anadolu ve Kıbrıs Türk halk masalları birçok kültürel unsuru barındırmakta ve söz konusu kültürel unsurların nesilden nesile aktarılmasında bir aracı görevi görmektedir. Her iki ülkenin masallarında çok fazla benzerliğin olması ortak tarih ve kökenlere bağlanabilir. Benzerliklerin yanında ayrışan veya farklılaşan bazı özelliklerin ise yaşanılan coğrafyadan ve şartlardan kaynaklandığını söylemek mümkündür. Kıbrıs Türkleri 1571'de Anadolu'dan Kıbrıs adasına gelirken doğal 
olarak yeni çevreye ve şartlara uyum sağlamışlar ve yaşanılan coğrafyadaki diğer kültürlerle (Rum, İngiliz) de iletişime geçmişler ve bu durumun etkisiyle bazı farklılaşmalar yaşamışlardır. Bu anlamda incelenen masallarda yer alan benzerlikler kadar farklılaşmaların da bir sürece bağlı olduğu ve doğal karşılanması gerektiği söylenebilir.

\section{EXTENDED ABSTRACT}

Tales are an important type of literature that contain unique elements with their structure, content, and function features, include motifs and descriptions, and are enriched with rhymes. When evaluated in terms of content features, folk tales, which contain extraordinary elements in their essence, where time and place are not clear, and usually have a happy ending, also include several cultural elements. Folk tales, which melt many features of the society to which they belong, especially in terms of socio-cultural elements, implicitly contain the subconscious of the society and people and provide important information to researchers about the structure of a given society. Tales, which are the products of oral folk literature, reach our day by passing centuries and through the appreciation of the Turkish people. Tales also fulfill a very important function for future generations in terms of learning about the customs and traditions of the society they belong to, their way of belief, their outlook on life, their expectations; in short, all their social and cultural characteristics. In this sense, it is possible to say that especially folk tales are very valuable, and that the tales are used by every society in transferring some national values and social rules to children.

In this study, the similarities between Anatolian and Northern Cyprus Turkish folk tales were compared in the cultural context, and the elements determined from this point of view were interpreted. The sample of the study consists of 40 tales (20 Anatolia -20 Cyprus) selected from the Turkish folk tales of Anatolia and Cyprus. Anatolian Turkish folk tales were selected from Ali Berat Alptekin's (2002) Taşeli Tales, Saim Sakaoğlu's (2002) Gümüşhane and Bayburt Tales, and Naki Tezel's (1992) Turkish Tales II. The Turkish Cypriot folk tales, on the other hand, were taken from Oğuz Yorgancıoğlu's book, Compilations from Turkish Cypriot Folklore-Tales II (2006).

Based on the aforementioned purpose, various fields of culture are included in the article. Deductions were made based on determinations about spaces, household goods, types of economy, public economy, profession, nutrition-kitchen and cellars, measuring-weighing-calculating units, clothing and ornaments, folk medicine, folk beliefs, customs, habits, traditions, transition periods, hospitality, religious-magical beliefs, practices, folk literature, folk sports, adult and children's games, vehiclestransport techniques, folk arts, and crafts.

In the examination, it has been seen that Anatolian and Turkish Cypriot folk tales contain several cultural elements and they constitute an intermediary task in the transfer of these cultural elements from generation to generation. It is possible to explain the many similarities in the tales of both countries with common history and origins. In addition to the similarities, it can be said that some distinguishing or differentiating features arise from the geography and conditions in which the respective peoples live. When Turkish Cypriots came to the island of Cyprus from 
Anatolia in 1571, they naturally adapted to the new environment and conditions, contacted other cultures (Greek, British) in the geography they lived in, and experienced some differentiation with the effect of this situation. In this sense, it can be said that the differences as well as the similarities in the examined tales depend on a process and should be considered natural. 


\section{5ELढ̧UKTÜRKIYAT}

\section{KAYNAKÇA}

Alptekin, A. B. (2002). Taşeli masalları. Ankara: Akçağ Yayınları.

Altunbay, M. (2016). Temel bir değer olarak Dede Korkut'ta misafirperverlik ve izzeti ikram. Akademik Bakış Uluslararası Hakemli Sosyal Bilimler Dergisi, (56), 359-371.

Bars, M. E. (2017). Türk destanlarında mağara kültü üzerine bir değerlendirme. Journal of International Social Research, 10 (52), 75-82.

Bayat, F. (2006). Ana hatlarıla Türk şamanlığı. İstanbul: Ötüken Neşriyat AŞ.

Çetindağ, G. (2007). Türk kültüründe mağara motifi. Uluslararası Asya ve Kuzey Afrika Çalışmaları Kongresi tam metin kitabı cilt I içinde (443-455). Ankara: Atatürk Kültür, Dil ve Tarih Yüksek Kurumu Yayınları.

Ertaylan, İ. H. (1951). Falnâme. İstanbul: İstanbul Üniversitesi Yayınları.

Gökbulut, B. (2010). Kıbrıs Türk masalları ile Uygur Türk masalları üzerinde karşılaştırmalı bir araştırma (İnceleme-Metinler) (Yayımlanmamış doktora tezi). Ege Üniversitesi Sosyal Bilimler Enstitüsü, İzmir.

Gül, M., Uzun, R. N. ve Çebi, M. (2018). Türk kültürlerindeki geleneksel oyunlar ve sporlara yüzeysel bir bakış. Electronic Turkish Studies, 13(26), 655-671.

Gün, İ. ve Şimşek, B. (2011). Türkiye'de ve Kuzey Kıbrıs Türk Cumhuriyeti'nde üretilen hellim peynirlerinin bazı özelliklerinin karşılaştırılması. Harran Üniversitesi Ziraat Fakültesi Dergisi, 15(1), 43-53.

İçli, A. (2013). Türk kültüründe ocak anlayışı ve Ergani Deringöze Köyü'ndeki bir ocaklı aile. Karadeniz Uluslararası Bilimsel Dergi, 1(18), 95-101.

Kantarcıoğlu, S. (1991). Eğitimde masalın yeri. İstanbul: MEB Yayınları.

Köktürk, Ş. (2006). Türk destanlarında hapsedilme motifi. Türklük Bilimi Araştırmaları, (19), 383400.

Mear, H. (1992). Kıbrıs Türk toplumunda doğum evlenme ve ölüm ile ilgili adet ve inanışlar. Lefkoşa: KKTC Milli Eğitim ve Kültür Bakanlığı Yayınları.

Özarslan, M. (2005). Bir Halk Ekonomisi Örneği Olarak 'HAB' ve ‘Değişik/Denişik” Geleneği ve İşlevleri. Türkbilig, (10), 54-59.

Sakaoğlu, S. (1983). Kıbrıs Türk masalları. Ankara: Kültür ve Turizm Bakanlığı Yayınları.

Sakaoğlu, S. (2002). Gümüşhane ve Bayburt masalları. Ankara: Akçağ Yayınları.

Şimşek, E. (2001). Kıbrıs' ta anlatılan "Zengininan Fukara" adlı masal üzerine bir inceleme. Türk Dünyası Dil ve Edebiyat Dergisi, (11), 191-202.

Şimşek, E. (2001). Yukarıçukurova masallarında motif ve tip araştırması. Ankara: Kültür Bakanlığı Yayınları.

Tezel, N. (1992). Türk masalları II. Ankara: Kültür Bakanlığı Yayınları.

Turgunbayer, C. (2007). Türk dünyası destanlarında ortak motifler üzerine. Türk Dünyası Dil ve Edebiyat Dergisi, (24), 93-102.

Yeniasır, M. ve Gökbulut, B. (2017). Eğitimsel açıdan Uygur ve Kıbrıs Türk masal kahramanları bağlamında iletilen olumsuz mesajlar. Selçuk Üniversitesi Edebiyat Fakültesi Dergisi (SEFAD), (38), 307-324.

Yeniasır, M. ve Gökbulut, B. (2017). İsmail Bozkurt'un "Bir Gün Belki” isimli romanında Kıbrıs Türk folkloruna dair tespitler. Journal of History Culture and Art Research, 6(3), 492-504.

Yıldırım, A. ve Şimşek. H. (2013). Sosyal bilimlerde nitel araştırma yöntemleri. Ankara: Seçkin Yayıncilik.

Yorgancıoğlu, O. (2000). Kıbrıs Türk folkloru. Mağusa: Canbulat Basımevi.

Yorgancioğlu, O. (2006). Kibrıs Türk folklorundan derlemeler-masallar II. Mağusa: Canbulat Basımevi. 